\title{
A new Pliensbachian elasmobranch (Vertebrata, Chondrichthyes) assemblage from Europe, and its contribution to the understanding of late Early Jurassic elasmobranch diversity and distributional patterns
}

\author{
Sebastian Stumpf ${ }^{1}$ (i) $\cdot$ Jürgen Kriwet $^{1}$ (i)
}

Received: 12 October 2018 / Accepted: 8 April 2019 / Published online: 13 May 2019

(c) The Author(s) 2019

\begin{abstract}
Here we describe a new, previously unrecognized elasmobranch microfossil assemblage consisting of isolated dental material from late Pliensbachian marginal marine, near-shore deposits of Grimmen in north-eastern Germany. The faunal composition indicates close affinities to other European pre-Toarcian elasmobranch-bearing localities, as it is predominantly composed of Hybodontiformes (Hybodus reticulatus?, H. hauffianus?, Lissodus sp.), Synechodontiformes (Palidiplospinax enniskilleni, P. occultidens, Paraorthacodus sp., Sphenodus sp.), and Hexanchiformes (Notidanoides sp.), as well as teeth attributable of the enigmatic Early Jurassic galeomorph shark Agaleus dorsetensis. In addition, the here reported elasmobranch tooth assemblage includes the oldest undisputable fossil records of Orectolobiformes and Batomorphii, each being represented by a single complete tooth only. The orectolobiform specimen is reminiscent of hemiscyllids but left in open nomenclature due to its very generalized morphology preventing any taxonomic identification. The batomorph tooth, conversely, is characterized by a unique combination of morphological features, which allows the introduction of new genus and species, Antiquaobatis grimmenensis gen. et sp. nov. The fossil assemblage presented here contributes to our current knowledge of late Early Jurassic chondrichthyan diversity and distributional patterns, providing some support for the hypothesis that most modern neoselachian lineages were initially linked to marginal marine, near-shore environments, before moving into open marine, offshore habitats by the Toarcian.
\end{abstract}

Keywords Elasmobranchii $\cdot$ Hybodontiformes $\cdot$ Neoselachii $\cdot$ Pliensbachian $\cdot$ Early Jurassic $\cdot$ Germany

\section{Introduction}

Neoselachii form a highly diversified monophyletic group of marine vertebrates encompassing more than 1,100 extant species of sharks, rays, and skates (Compagno et al. 2005; Weigmann 2016). According to our current knowledge, neoselachians had their first appearance in the early Permian (Ivanov 2005), but they might have originated even earlier. Together with hybodontiform sharks, their supposed sister group that ranges from the Late Devonian to the Late

Handling Editor: Adriana López-Arbarello.

Sebastian Stumpf

sebastian.stumpf@univie.ac.at

1 Department of Palaeontology, University of Vienna, Geozentrum, Althanstraße 14, 1090 Vienna, Austria
Cretaceous (Ginter et al. 2002; Maisey et al. 2004; Coates and Gees 2007), neoselachians form the most dominant chondrichthyan lineage during the Mesozoic.

The late Early Jurassic is considered to mark a key time interval in the evolutionary history of neoselachian elasmobranchs, because the Toarcian witnessed a first major radiation event resulting in a significant taxonomic and ecological diversity increase (Underwood 2006; Kriwet et al. 2009; Guinot et al. 2012; Guinot and Cavin 2016). Obviously, it was the time when most crown-group neoselachians (i.e., Heterodontiformes, Orectolobiformes, Squantiniformes, and Batomorphii) became abundant in the fossil record for the first time (e.g., Thies 1983; Delsate and Lepage 1990, 1993; Delsate and Thies 1995; Delsate and Candoni 2001), suggesting an abrupt and nearly simultaneous colonization of a wide range of marine habitats (Underwood 2004, 2006), probably accompanied by a subsequent diversity decline of 
hybodontiforms within marine environments (e.g., Rees and Underwood 2008; Leuzinger et al. 2017). On the other hand, the Early Jurassic elasmobranch fossil record is strongly biased towards isolated material such as teeth and placoid scales from open marine, offshore environments; material from marginal marine, near-shore facies remains extremely rare due to the scarcity of productive localities (Rees 1998). This renders recognition of Early Jurassic elasmobranch macroevolutionary patterns and processes difficult (Underwood 2004, 2006). Therefore, any new information on late Early Jurassic elasmobranch fishes from marginal marine, near-shore settings potentially increases our knowledge about their taxonomic and ecological diversity, as well as their temporal and spatial distribution during this crucial time interval.

Here we present a new, previously unrecognized fossil elasmobranch assemblage recovered from late Pliensbachian marginal marine deposits of Grimmen
(Mecklenburg-Western Pomerania, north-eastern Germany), comprising isolated dental remains attributable to the Hybodontiformes and Neoselachii. The intention of this paper is (1) to describe the cartilaginous fish assemblage from the late Pliensbachian of Grimmen and (2) to discuss its significance for better understanding Early Jurassic elasmobranch diversity and distributional patterns.

\section{Geological and stratigraphic setting}

In north-eastern Germany, outcrops of Mesozoic strata are rare (see Katzung 2004; Petzka et al. 2004), and Early Jurassic strata crop out only in the now abandoned open-cast clay pits of Grimmen and Dobbertin (Fig. 1a), both giving access to parautochthonous successions of late Pliensbachian to early Toarcian marine sediments that were glacially
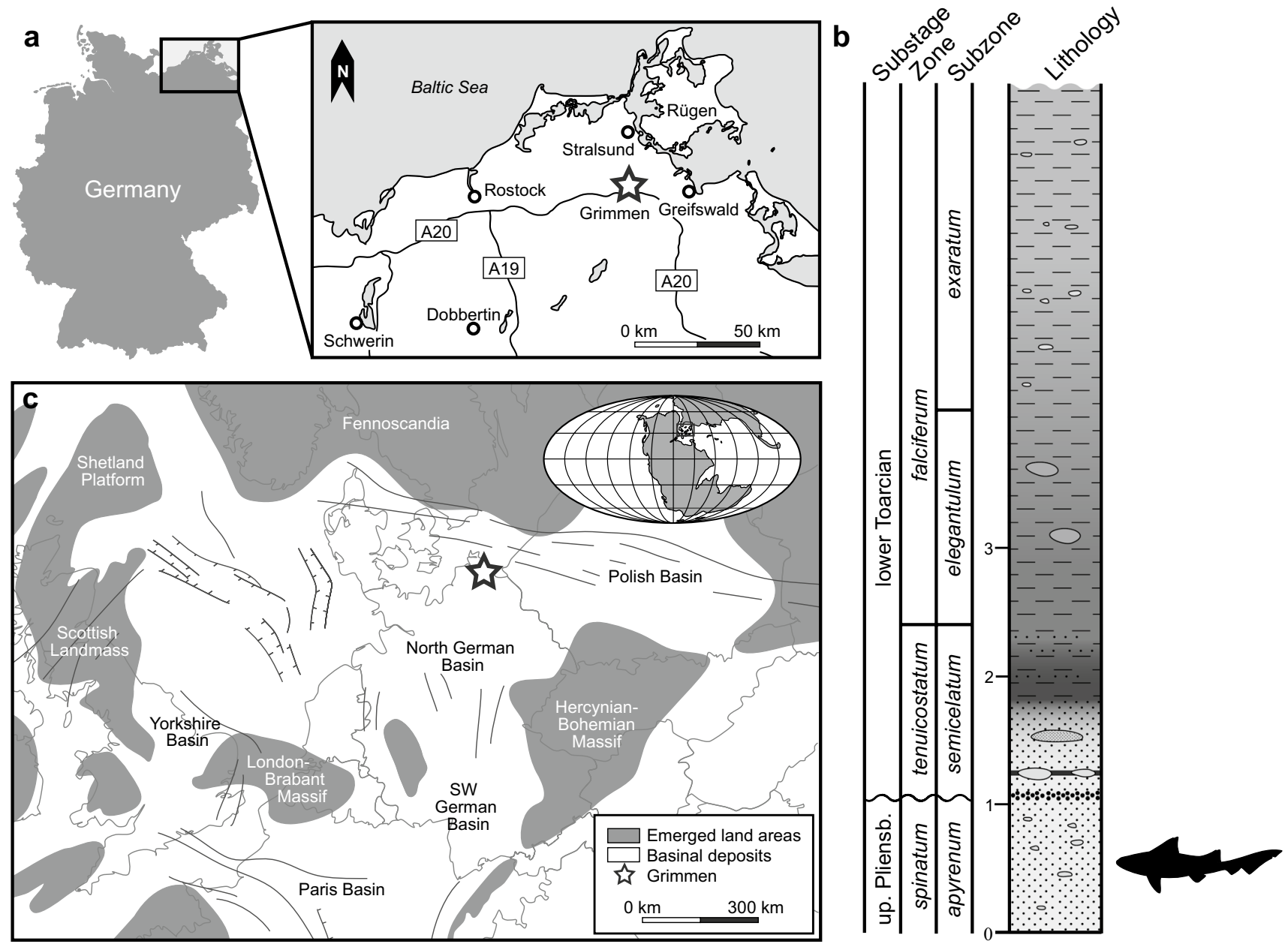

Fig. 1 a Geographical location map; b stratigraphic standard section of the late Early Jurassic succession exposed in the abandoned Grimmen clay pit (wavy line indicates hiatus at the PliensbachianToarcian transition), with stratigraphic positions of elasmobranch occurrences reported here; c rough reconstruction of PliensbachianToarcian paleogeography of central and western Europe (modified from Stumpf et al. 2017) 
dislocated during Pleistocene ice advances (see Ernst 1967, 1991, 1992; Ansorge 2007; Ansorge and Obst 2015).

The abandoned Grimmen clay pit $\left(54^{\circ} 87^{\prime} 53.53^{\prime \prime} \mathrm{N}\right.$, $13^{\circ} 83^{\prime} 29.88^{\prime \prime} \mathrm{E}$ ) is not accessible any more, and is covered by vegetation and filled with water. The late Pliensbachian interval of Grimmen consists of unlithified fine-grained sands containing thin beds of silt, and subordinate lenticular streaks of clay, as well as laterally limited fine- to coarsegrained, bioclastic-rich sand bodies, which are indicative of local accumulations generated by current activity, suggesting a marginal, shallow-marine depositional environment (Ernst 1967, 1991; Ernst in Gründel 1999). Biostratigraphically, this interval has been correlated with the apyrenum subzone (lower spinatum zone) based on ammonite evidence (Ernst 1967, 1991; Buchholz 2012), which is ca. 184 Ma. The Pliensbachian-Toarcian transition is omitted due to a hiatus, probably caused by erosion and/or non-deposition (see Röhl and Schmid-Röhl 2005), and therefore, the uppermost spinatum zone (hawskerense subzone) and probably much of the early Toarcian tenuiscostatum zone (paltum to clevelandicum subzone) are absent (Ernst 1991). The early Toarcian interval is represented by fine-grained sands that pass upwards into black bituminous, laminated silty clays referred to the latest tenuiscostatum zone (semicelatum subzone), ca. $183 \mathrm{Ma}$, and finally into pure clays assigned to the slightly younger lower falciferum zone (elegantulum to exaratum subzone). Palaeogeographically, the late Early Jurassic succession of Grimmen was deposited at the northeastern edge of the North German Basin, which formed one of the many sub-basins that covered large areas of central and western Europe during Early Jurassic times (Fig. 1c).

The clayey lower Toarcian interval (elegantulum to exaratum subzone) of Grimmen is renowned for having produced a diverse fauna of vertebrates, including fish, secondarily marine reptiles, and dinosaurs (e.g., Haubold 1990; Thies 1989; Maisch and Ansorge 2004; Konwert and Stumpf 2017; Stumpf 2016; Stumpf et al. 2015, 2017; Maxwell and Stumpf 2017; Konwert and Hörnig 2018). Likewise, vertebrate material also has been reported from the upper Pliensbachian of Grimmen (e.g., Ernst 1967, 1991; Kutscher 1988; Buchholz 2012; Stumpf et al. 2017), but little detailed taxonomic research has been conducted, and a comprehensive study of the vertebrate fauna thus has not been provided so far.

Vertebrates from the upper Pliensbachian interval of Grimmen are represented by isolated actinopterygian and chondrichthyan remains only, including teeth, scales, and otoliths. The fossil material is fragmentary and has suffered from erosion in many places, with some teeth and scales displaying distinct patterns of bioerosion probably attributable to endolithic microorganisms (see below).
Significantly, the Pliensbachian-Toarcian transition and the immediately following Toarcian-Oceanic Anoxic Event (T-OAE) mark two global episodes of palaeoenvironmental perturbations that were accompanied by well-known secondorder mass extinctions of marine invertebrate biota (e.g., Little and Benton 1995; Cecca and Macchioni 2004; Wignall et al. 2005; Caswell et al. 2009; Dera et al. 2010; Caruthers et al. 2014; Rita et al. 2016), a pronounced eustatic sea-level rise (e.g., Hallam 2001; Haq 2017), and a marked increase in seawater temperature associated with global warming (e.g., Hesselbo and Jenkyns 1998; Bailey et al. 2003; Rosales et al. 2004; Gómez et al. 2008; Suan et al. 2010; Korte and Hesselbo 2011). The upper Pliensbachian of Grimmen therefore documents a marginal marine ecosystem immediately before the two global palaeoenvironmental perturbation episodes that occurred at and immediately following the Pliensbachian-Toarcian transition. Therefore, this fauna is of utmost importance for understanding the intensity of these perturbations and also of possible recovery events in the aftermath of the T-OAE.

\section{Materials and methods}

The fossil material that forms the focus of the present study was collected by geoscientists and private collectors via screen-washing and sieving sediment samples obtained from temporary late Pliensbachian exposures accessible during the period of active clay mining at the Grimmen site, which started in 1959/1960 and ended in 1995 (see Petzka et al. 2004; Ansorge 2007). Unfortunately, the clay pit is not accessible any more so that it is not possible to provide detailed information about the collecting sites or fossiliferous horizons. The material is now housed at the Institute of Geography and Geology (GG), University of Greifswald, and the Geological State Collection of Western-Pomerania (MV), Sternberg.

Digital photographs presented in the text were obtained using digital macro- and microphotography and a scanning electron microscope (SEM). Specimens shown in Figs. $2 \mathrm{j}-\mathrm{O}$, 3a-f, $4 \mathrm{a}-\mathrm{d}, \mathrm{m}-\mathrm{p}$ were coated with gold/palladium for SEM analysis.

\section{Systematic palaeontology}

Remarks. The taxonomy and systematics for hybodontiform sharks follow those of Rees and Underwood (2002) and Rees (2008), and those for neoselachians follow Klug (2010) and Kriwet and Klug (2011, 2014, 2016). The descriptive terminology for teeth largely corresponds to that of Cappetta (2012) 
Class Chondrichthyes Huxley, 1880

Subclass Elasmobranchii Bonaparte, 1838

Cohort Euselachii Hay, 1902

Order Hybodontiformes Maisey, 1975

Superfamily Hybodontoidea Owen, 1846

Family Hybodontidae Owen, 1846

Subfamily Hybodontinae Owen, 1846

Genus Hybodus Agassiz, 1837

Type species. Hybodus reticulatus Agassiz, 1837 from the Sinemurian (Early Jurassic) of Lyme Regis, England.

Hybodus reticulatus Agassiz, 1837 ?

Figure 2a-f

Material. Thirteen incomplete teeth (GG 438/1-5; MV 202616/1-8).

Description. The teeth are represented by isolated tooth crowns lacking the roots and lateral cusplets. The cusps are high, labio-lingually compressed, and display moderately well-developed cutting edges (Fig. 2c, e). The cusps are slightly inclined distally (Fig. 2a, b, d, f) and straight in mesio-distal views (Fig. 2c). The ornamentation consists of simple, weak to moderately well-developed vertical folds covering the lower parts of the cusps (Fig. 2a, b, d, f). Labial nodes at the base of the crown are absent.

Discussion. The high and labio-lingually narrow tooth crown morphology, combined with the presence of simple, nonbifurcating enameloid folds covering the lower part of the cusp, and the absence of nodes along the base of the labial side of the crown are dental characters that are consistent with teeth of Hybodus reticulatus Agassiz, 1837, the type species of Hybodus, thus separating the above-described teeth from those of all other Hybodus species reported from the Early Jurassic (see Duffin 1993, 1997, 2010 for discussion). However, as is widely accepted, the genus Hybodus represents an unnatural grouping of unrelated taxa (Rees and Underwood 2002, 2006, 2008; Rees 2008; Maisch and Matzke 2016), and a revision of this taxon is needed for better understanding the taxonomic content of Jurassic hybodontiforms. Teeth of $H$. reticulatus are very similar to those of Egertonodus Maisey, 1987, which is known from dental and skeletal material ranging from the Middle Jurassic to the Early Cretaceous (e.g., Patterson 1966; Maisey 1987; Rees and Underwood 2008; Bermúdez-Rochas 2009), but teeth of Egertonodus are otherwise characterized by displaying a higher and more slender main cusp that is sigmoidally curved in mesio-distal views.
Early Jurassic fossil records traditionally referred to the genus Hybodus are known from several European localities, with $H$. reticulatus being previously known from both isolated teeth and disarticulated skeletal material ranging from the middle Hettangian to the early Pliensbachian (Woodward 1889; Maisey 1987; Delsate and Duffin 1993; Duffin 1993; Rees 1998; Delsate et al. 2002). In addition, Maisey (1987) reported $H$. cf. reticulatus from the Toarcian of southern Germany, an assignment later rejected by Duffin (1997). Given its limited and fragmentary nature, the Grimmen material is here tentatively assigned to $H$. reticulatus, potentially extending the stratigraphic range of this species to the late Pliensbachian.

Hybodus hauffianus Fraas, 1895?

Figure $2 \mathrm{~g}-\mathrm{i}$

Material. Eight incomplete teeth (GG 438/6-11; MV 202618/1, 2).

Description. The teeth are represented by incomplete and, in many cases, strongly abraded tooth crowns lacking roots and lateral cusplets. The cusps are labio-lingually compressed, with the cross-section being circular to slightly oval in occlusal view (Fig. 2h). The ornamentation is composed of distinct nodes arranged along the base of the labial side of the cusp (Fig. 2g, h), and moderate to strongly developed vertical folds covering the labial and lingual sides of the crown (Fig. 2g, i). These folds occasionally branch off towards the base of the crown. The cutting edges are moderately well-developed (Fig. 2h).

Discussion. Although being in poor state of preservation, the labio-lingually slender morphology and overall ornamentation pattern displayed by the above-described teeth indicate closest morphological affinities to teeth of Hybodus hauffianus Frass, 1895 from the Toarcian of Germany, which is considered to be very similar to $H$. reticulatus in both, dental and skeletal morphology (Maisey 1987; Duffin 1997). One of the most important dental features for distinguishing teeth of $H$. hauffianus from those of $H$. reticulatus is the presence of labial nodes (Duffin 1997). Dental characteristics similar to those of $H$. hauffianus also occur in $H$. cloacinus Quenstedt, 1858, which is known from teeth ranging from the Rhaetian to the Sinemurian (Duffin 1993, 2010), but unlike in $H$. hauffianus, teeth of $H$. cloacinus exhibit rather moderate central cusps and a more strongly developed crown ornamentation with vertical ridges reaching the cusp apices. For this reason, and given the rather high and labiolingually slender tooth crown morphology, the here described material from the late Pliensbachian of Grimmen is tentatively 


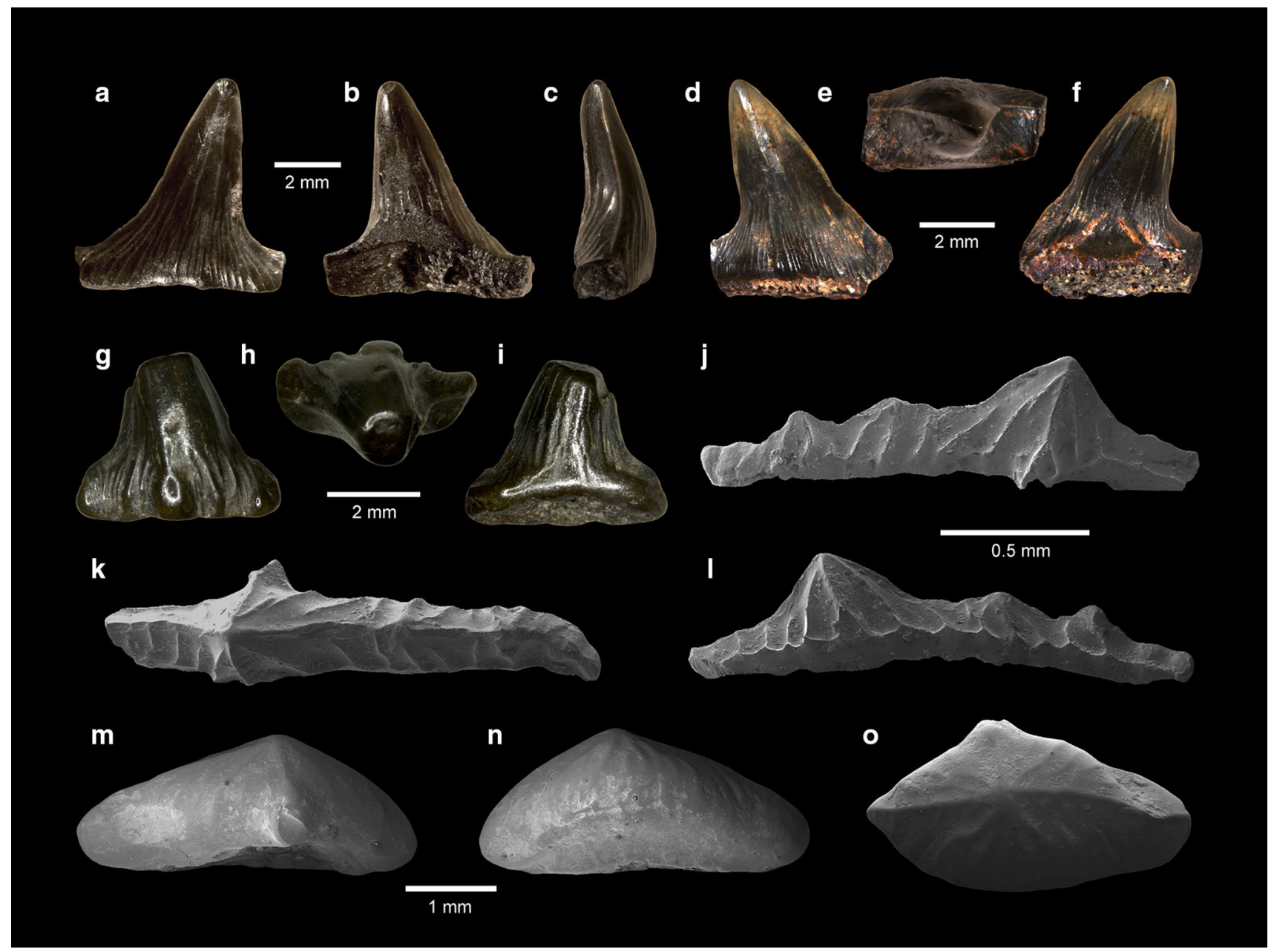

Fig. 2 Hybodontiform shark teeth from the upper Pliensbachian of Grimmen (Mecklenburg-Western Pomerania, NE Germany). a-f Hybodus reticulatus Agassiz, 1837?, lateral tooth (GG 438/1) in labial (a), lingual (b), and mesial (c) view; lateral tooth (MV 202616/1) in labial (d), occlusal (e), and lingual (f) views; g-i Hybo-

referred to as $H$. hauffianus, potentially representing the oldest fossil record of this species.

\section{Family Lonchidiidae Herman, 1977}

Incertae subfamiliae

Lonchidiidae gen. et sp. indet.

Figure $2 \mathrm{j}-1$

Material. One incomplete tooth (GG438/29).

Description. The specimen is represented by an almost complete lateral tooth crown lacking its root. The crown is gracile, labio-lingually narrow, and markedly mesiodistally elongated. In labio-lingual aspect, the crown has a low profile, exhibiting a moderately high, triangular blunt principal cusp that is slightly inclined distally (Fig. $2 \mathrm{j}, 1$ ). dus hauffianus Fraas, 1895?, lateral tooth (GG 438/6) in labial (g), occlusal (h), and lingual (i) aspects; $\mathbf{j}-\mathbf{l}$ Lonchidiidae gen. et sp. indet., postero-lateral tooth (GG438/29) in labial (j), occlusal (k), and lingual (l) aspects; m-o Lissodus sp., lateral tooth (MV 202619/1) in labial (m), lingual (n), and occlusal (o) views

The principal cusp is flanked mesially by four cusplets. The number of distal cusplets flanking the principal cusp remains unknown due to breakage. A moderately well-developed labial protuberance is present, exhibiting a vertical crest that reaches the apex of the principal cusp (Fig. 2j, k). Labial and lingual nodes along the crown base are absent. In occlusal view, a moderately well-developed crest runs along the entire length of the crown (Fig. 2k). The ornamentation is composed of rather strong vertical to subvertical enameloid folds. They begin at the crown shoulder but attain neither the cusps nor the occlusal crest in most cases. The enameloid folds covering the lingual face of the crown coalesce basally to form a somewhat serrated or reticulated ridge that extends horizontally along the crown shoulder (Fig. 21).

Discussion. The gracile, labiolingually narrow and mesiodistally elongated tooth crown architecture, and the 
possession of a distinct principal cusp and cusplets, together with the presence of a rather weak labial protuberance are dental features resembling those of the lonchidiid Parvodus Rees and Underwood, 2002. However, the more complex lingual ornamentation pattern disagrees with the characters provided in the original diagnosis, and thus separates specimen GG 438/29 from teeth of Parvodus, which suggests that this specimen belongs to a new, as yet unnamed lonchidiid or closely related form. Consequently, GG 438/29 is here tentatively referred to as Lonchidiidae gen. et sp. indet. until more material becomes available for study.

Incertae familiae et subfamiliae

Genus Lissodus Brough, 1935

Type species. Hybodus africanus Broom, 1909 from the Lower Triassic of Bekker's Kraal, South Africa.

\section{Lissodus sp.}

Figure $2 \mathrm{~m}-\mathrm{o}$

Material. Two partially preserved teeth (MV 202619/1, 2).

Decription. The teeth are up to $4 \mathrm{~mm}$ mesio-distally wide and display a somewhat triangular to oval outline in occlusal view (Fig. 2o). The crown is moderately high and exhibits a slightly demarcated principal cusp (Fig. $2 \mathrm{~m}$, n). Lateral cusplets are absent. In both labio-lingual and mesio-distal aspects, the crown is smoothly rounded laterally. The crown forms a moderate protuberance at the base of the labial crown face (Fig. $2 \mathrm{~m}$, o). There is a weakly developed occlusal crest running along the entire length of the crown. Further ornamentation includes very weak vertical folds descending from the principal cusp apex and from the occlusal crest laterally. In some cases, these ridges bifurcate basally towards the crown shoulder (Fig. 2o).

Discussion. The general morphology and ornamentation pattern seen in these teeth warrants an inclusion in the genus Lissodus Brough, 1935 (see Rees and Underwood 2002). The familial placement of Lissodus within Hybodontiformes, however, remains ambiguous and unresolved, because this genus is characterized by a rather unique combination of dental and cephalic spine morphologies (Rees 2008). Lissodus encompasses numerous described nominal species, and reported occurrences of this taxon are nearly globally distributed, being reported from both marine and non-marine deposits of Late Devonian to Early Cretaceous age (Ginter et al. 2002; Rees and Underwood 2002). So far, three species of Lissodus have been described from the Early Jurassic: L. johnsonorum Milner and Kirkland, 2006 from the
Hettangian of Utah, USA, L. hasleensis Rees, 1998 from the Pliensbachian of Bornholm, Denmark, and L. guenneguesi Delsate, 2003 from the Toarcian of Luxembourg. The validity of L. guenneguesi, however, needs to be re-evaluated, since this species is known only from a few incomplete and fragmentary preserved teeth.

The Grimmen teeth display dental features consistent with the diagnosis of L. johnsonorum provided by Milner and Kirkland (2006), including a low crown profile, the presence of a principal cusp without lateral cusplets, a moderate labial protuberance, and a weakly developed ornamentation consisting of simple, mainly non-bifurcated folds. However, the North American species L. johnsonorum is based on fossil material recovered from exclusively lacustrine deposits, making a positive attribution of the Grimmen material to $L$. johnsonorum very unlikely. Otherwise, similar dental characteristics also have been described for lateral teeth of L. minimus (Agassiz, 1839) from the Rhaetian of England, as well as for teeth of the British Middle Jurassic species L. leiodus Woodward, 1887 (see Duffin 1985; Rees and Underwood 2006; Nordén et al. 2015). Lateral teeth of the L. minimus, however, are considerably more elongated in the mesio-distal direction and bear a small, inconspicuous labial protuberance, unlike the Grimmen teeth. Teeth of L. leiodus are characterized by displaying a distinct, knob-like labial protuberance. Consequently, the Grimmen material cannot be assigned to any described Lissodus species with certainty, and it therefore is referred to as Lissodus sp. here.

\section{Subcohort Neoselachii Compagno, 1977}

Incerti superordinis

Order Synechodontiformes Duffin and Ward, 1993

Family Palaeospinacidae Regan, 1906

Genus Palidiplospinax Klug and Kriwet, 2008

Type species. Synechodus enniskilleni Duffin and Ward, 1993 from the Sinemurian (Early Jurassic) of Lyme Regis, England.

Palidiplospinax enniskilleni (Duffin and Ward, 1993)

Figure $3 \mathrm{a}, \mathrm{b}$

Material. One complete tooth (GG 438/35).

Description. The single specimen GG $438 / 35$ is represented by an almost complete lateral tooth measuring $2.46 \mathrm{~mm}$ in total width and $1.18 \mathrm{~mm}$ in maximum height. The tooth crown is labio-lingually compressed and displays a welldefined and slightly distally inclined triangular principal cusp, which is asymmetrically flanked by well-separated cusplets, including one distal and two mesial cusplets 


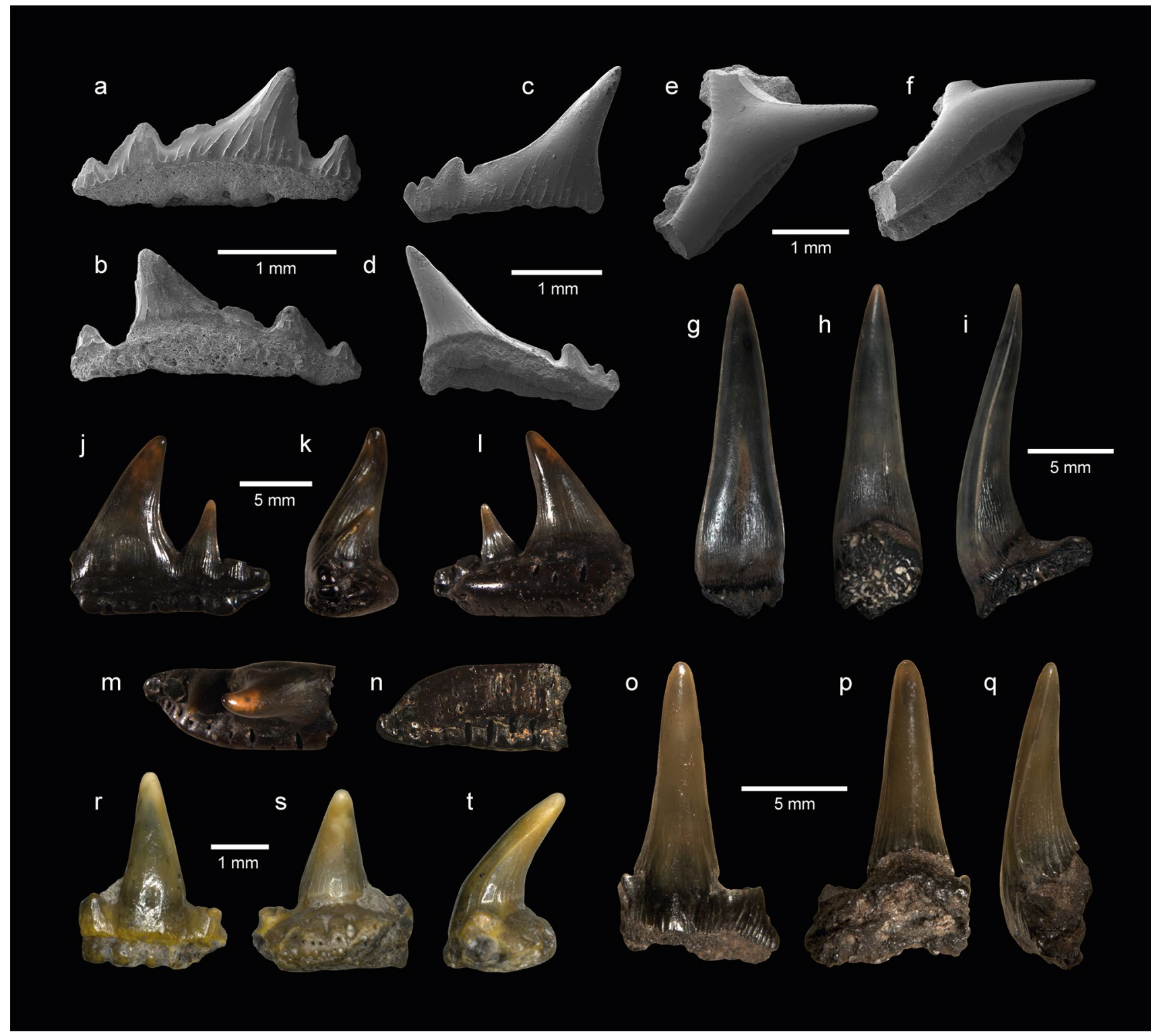

Fig. 3 Neoselachian stem-group representatives from the upper Pliensbachian of Grimmen (Mecklenburg-Western Pomerania, NE Germany). a, b Palidiplospinax enniskilleni (Duffin and Ward, 1993), lateral tooth (GG 438/35) in labial (a) and (b) lingual views; c-f Palidiplospinax occultidens (Duffin and Ward, 1993), lateral tooth (GG 438/36) in labial (c) and (d) lingual aspects; lateral tooth (GG 438/37) in (e) labial and (f) oblique mesial views; g-i Sphenodus

(Fig. 3a, b). The cutting edges are well-developed and sharp. The ornamentation is composed of strong non-bifurcating vertical folds, which ascend above the crown-root junction to cover most part of the crown. The root is slightly eroded but appears to have been projected lingually. The labial root face displays two large basally placed foramina and possible remnants of a nutritive groove (Fig. 3a). The lingual face of the root bears several tiny foramina that are aligned in a more or less horizontal line (Fig. 3b). sp., anterior tooth (GG 438/41) in (g) labial, (h) lingual, and (i) lateral aspects; j-t Paraorthacodus sp., lateral tooth (MV 202621/1) in (j) labial, (k) distal, (l) lingual, (m) occlusal, and (n) basal views; anterior tooth (GG 438/42) in labial (o), lingual (p), and (q) lateral views; parasymphesial tooth (MV 202621/2) in (r) labial, (s) lingual, and (t) lateral aspects

Discussion. Synechodontiformes includes four phylogenetically well-supported families, including Palaeospinacidae, Pseudonotidanidae, Orthacodontidae, and Paraorthacodontidae (Klug 2010), and according to the fossil record, the stratigraphic range of Synechodontiformes is Late Permian to Palaeocene. Klug and Kriwet (2008) introduced the palaeospinacid genus Palidiplospinax to include the following three Early Jurassic European species: P. enniskilleni (Duffin and Ward, 1993), P. occultidens (Duffin and Ward, 1993), 
and P. smithwoodwardi (Fraas, 1896). Of these, P. enniskilleni and $P$. occultidens are by far the most common species, as they are known from both skeletal and dental remains ranging from the Hettangian to the Pliensbachian (Delsate and Duffin 1993; Duffin and Ward 1993; Rees 1998, 2000; Duffin 2010). Conversely, P. smithwoodwardi is a very rare species known from a single incomplete skeleton recovered from the lower Toarcian of Germany (Klug and Kriwet 2006, 2008).

Palidiplospinax was found to be dentally and skeletally very similar to Synechodus Woodward, 1888 and Paraorthacodus Glikman, 1957 by Klug and Kriwet (2008), and in a subsequent phylogenetic analysis conducted by Klug (2010), Palaeospinacidae was resolved to include Palidiplospinax, Synechodus, and 'Synechodus' prorogatus Kriwet, 2003, with Palidiplospinax occupying the most basal position within this clade, while Paraorthacodus was resolved as a member of a new synechodontiform family, Paraorthacodontidae, together with Macrourogaleus Fowler, 1947.

The single tooth GG 438/35 from the upper Pliensbachian of Grimmen fits well with dental characteristics described for lateral teeth of $P$. enniskilleni, thus separating it from those of $P$. occultidens, which are characterized by exhibiting a less pronounced crown ornamentation and fewer, less well-developed lateral cusplets (Duffin and Ward 1993; Duffin 2010). Rees (2000) described two teeth of P. enniskilleni from the Pliensbachian of southern Sweden, but he also noted morphological differences from the holotype material from the Sinemurian of England described by Duffin and Ward (1993). Unfortunately, the dentition of $P$. smithwoodwardi is unknown and therefore the Swedish teeth might be best identified as Palidiplospinax sp. On the other hand, the dental differences observed by Rees (2000) might also be attributable to sexual dimorphism in P. enniskilleni (see Klug et al. 2009; Klug and Kriwet 2013), but more articulated material is needed to test this hypothesis.

Palidiplospinax occultidens (Duffin and Ward, 1993) Figure $3 \mathrm{c}-\mathrm{f}$

Material. Ten incomplete teeth (GG 438/36-40; MV 202620/1-5).

Description. The teeth are characterized by rather stout and bulky cusps. The cusps are pointed and lingually curved, with their apices overhanging the root (Fig. 3e, f). In mesio-distal aspects, the cusps are slightly sigmoidal. Laterally, the cusps are flanked by extended heels bearing up to three smaller cusplets at the lateral edges (Fig. 3c, d). The cutting edges are continuous but weakly developed (Fig. 3e, f). The ornamentation is composed of faint vertical folds on both the labial and lingual faces of the crown. The folds are restricted to the lower part of the crown and are usually more pronounced on the lingual face. The roots are well-developed and slightly U-shaped in basal view, showing a pseudopolyaulacorhize vascularisation pattern. The roots are slightly projected lingually and exhibit small circular to oval nutritive foramina penetrating the lingual root face (Fig. 3f). The labial face of the root bears a horizontally arranged row of rather large nutritive foramina that are notched into the basal root face (Fig. 3e).

Discussion. These teeth can be unequivocally attributed to Palidiplospinax occultidens, whose teeth are defined by possessing inconspicuously ornamented crowns with laterally extended heels and reduced lateral cusplets (Duffin and Ward 1993; Duffin 2010).

Family Orthacodontidae Glikman, 1957

Genus Sphenodus Agassiz, 1843

Type species. Lamna longidens Agassiz, 1843 from the Oxfordian (Late Jurassic) of Mont Vohaye, Switzerland.

\section{Sphenodus sp.}

Figure $3 \mathrm{~g}-\mathrm{i}$

Material. One incomplete tooth (GG 438/41).

Description. Specimen GG 438/41 is the largest tooth within the here reported fossil assemblage, measuring $19.6 \mathrm{~mm}$ in maximum height. It possesses a high and erect cusp that is lingually curved and slightly sigmoidal in mesio-distal views (Fig. 3i), exhibiting continuous and well-developed cutting edges (Fig. 3g, h). The cusp displays no torsion along their lengths and there are neither lateral blades nor cusplets. The labial face of the cusp is only slightly convex, while the lingual face is strongly convex. The ornamentation consists of fine and densely arranged vertical enameloid folds arranged along the lower parts of the labial (Fig. 3g) and lingual (Fig. 3h) faces of the cusp, with the ornamentation on the lingual side being slightly more well-defined. The root lacks any significant morphological features as it is only partially preserved.

Discussion. The genus Sphenodus Agassiz, 1843, includes numerous described species ranging from the Sinemurian to the Danian (see Duffin and Ward 1993). However, the fossil record of Sphenodus is predominantly based on isolated teeth or even isolated tooth crowns, with most species showing very similar dental characteristics. In consequence, most Sphenodus species are dubious and in need of revision 
to ensure their validities (e.g.,Kriwet et al. 2006; Adolfssen and Ward 2014).

There are three well-known Jurassic Sphenodus species: S. macer (Quenstedt, 1851) and S. nitidus Wagner, 1862 from the German Late Jurassic (e.g., Böttcher and Duffin 2000; Kriwet and Klug 2004, 2008, 2015), and S. longidens Agassiz, 1843, which has been reported from several European localities of Early to Late Jurassic age (e.g., de Beaumont 1960; Thies 1993; Kriwet and Klug 2004; Rees 2010; Simonsen 2012). The Sphenodus tooth from the upper Pliensbachian of Grimmen significantly differs from those of S. longidens, S. macer, and S. nitidus in the more robust tooth crown morphology and the presence of a more pronounced ornamentation, thus precluding a positive assignment to any of the aforementioned species. Rees (2000) described teeth referred to Sphenodus sp. from the upper Pliensbachian of southern Sweden, but noted that this material may comprise teeth of at least two unrelated genera (Rees 2010), pending further taxonomic research. The partial tooth crown figured by Rees (2000: Fig. 3d-f) appears to be quite similar to the Grimmen specimen, but its incomplete nature prohibits a detailed comparison.

\section{Family Paraorthacodontidae Klug, 2010}

\section{Genus Paraorthacodus Glikman, 1957}

Type species. Synechodus recurvus Trautschold, 1877 from the Cenomanian (Late Cretaceous) of the Volga region, Russia.

\section{Paraorthacodus sp.}

Figure $3 \mathrm{j}-\mathrm{t}$

Material. Forty-one mostly incomplete teeth (GG 438/4248; MV 202621/1-34).

Description. The material includes parasympheseal and lateral teeth as well as numerous isolated cusps. The parasympheseal teeth are rather small, measuring up to $3.6 \mathrm{~mm}$ in total height. They are characterized by a prominent and rather stoutly built principal cusp that is flanked laterally by a pair of minute cusplets (Fig. 3r, s). The principal cusp is bent lingually without sigmoidal curvature (Fig. 3t). Its ornamentation consists of a few simple and weakly developed vertical folds covering the lower portion of the labial face (Fig. 3r). Lingually, the ornamentation is composed of fine, non-bifurcating and evenly distributed vertical folds that are restricted to the lower half of the crown (Fig. 3s). The cusplets flanking the principal cusp exhibit a few weakly developed vertical folds on their labial faces (Fig. 3r); lingually they are devoid of any ornamentation (Fig. 3s). The principal cusp bears continuous and well-developed cutting edges, unlike in the lateral cusplets, where no cutting edges could be observed.

The root is prominent and projected lingually, showing a pseudopolyaulacorhize vascularisation pattern with basally open nutritive grooves arranged along the labial face of the root (Fig. 3r). Lingually, the root is pierced by numerous, irregularly arranged nutritive foramina of varying sizes (Fig. 3s, t).

Lateral teeth have up to three well separated cusplets adjacent to the principal cusp, and the best-preserved specimen (Fig. 3j-n) measures $14.3 \mathrm{~mm}$ in maximum width and $13.0 \mathrm{~mm}$ in total height. The principal cusp is rather stout with a bulky base displaying an elliptical to subcircular crosssection. The labial face is flat to slightly concave in its lower portion above the tooth-crown junction and flat to slightly convex in its upper portion (Fig. 3j). The lingual face is evenly convex. The principal cusp has a sigmoidal profile in mesiodistal views (Fig. 3k), and it is either straight or slightly bent distally. Both the labial and lingual faces of the cusp are ornamented by fine and evenly distributed ridges that cover most part of the cusp starting above the tooth-crown junction to reach the upper two-thirds of the cusp (Fig. 3j-1). The cusplets are well-developed, subcircular in cross-section, and slightly bent lingually (Fig. $3 \mathrm{k}, \mathrm{m}$ ), with fine vertical ridges covering both the labial and lingual faces reaching the apices (Fig. 3j-k). The cutting edges are well-defined and continuous between principal cusp and lateral cusplets.

The root is slightly projected lingually displaying several foramina aligned along the upper portion of the lingual root side (Fig. 31, m). The vascularisation pattern is of the pseudopolyaulacorhize type showing several nutritive groove openings along the labial face of the root (Fig. 3j). The labial grooves are basally open, extending lingually about onethird the labiolingual width of the root base (Fig. 3n).

The isolated cusps are high and erect with a flat to slightly convex labial face and an evenly convex lingual face (Fig. 3o-q). The cross-section is subcircular and there is no sigmoidal curvature (Fig. 3q). There are vertical ridges covering the lower half of the cusp on both the labial and the lingual side of the crown. On the lingual side, these ridges are stronger and more densely arranged (Fig. 3p, q). Roots and lateral cusplets are incomplete or even missing.

Discussion. The genus Paraorthacodus Glikman, 1957 includes numerous described species ranging from the Pliensbachian to the Palaeocene (see Duffin and Ward 1993; Klug et al. 2009), and it is almost exclusively known from isolated dental material, except for the European Late Jurassic to Early Cretaceous species $P$. jurensis (Schweizer, 1964) (see Guinot et al. 2014), whose fossil record includes exceptionally well-preserved holomorphic specimens reported from the Kimmeridgian and Tithonian of southern Germany (Klug et al. 2009; Kriwet and Klug 
2015). The distinction between Jurassic Paraorthacodus species remains unresolved, which is mainly the result of very similar tooth morphologies and the poor sampling effort. The oldest known species referred to Paraorthacodus is P. arduennae described by Delsate (2001) based on a few teeth recovered from Pliensbachian of northern France. Teeth of $P$. arduennae are characterized by displaying a reduced ornamentation pattern along the labial face of the crown, where vertical ridges can be either restricted to the lateral cusplets flanking the principal cusp or even completely absent, separating it from the Grimmen teeth. Unfortunately, the figures provided by Delsate (2001) are too insufficient to provide any additional morphological features useful for taxonomic differentiation. In addition, Biddle (1993) described teeth from the upper Pliensbachian of western France, which he referred to $P$. kruckowi Thies, 1983, a poorly known species initially based on two teeth recovered from the Aalenian of Germany. In addition, Rees $(1998,2000)$ reported fragmentary teeth that he assigned to Paraorthacodus sp. from the Pliensbachian of Sweden and Denmark. However, the incomplete nature of the Scandinavian material precludes a proper comparison. The Grimmen teeth, especially the lateral ones, indicate close similarities to those of $P$. kruckowi, but otherwise it cannot be ruled out whether the herein presented material forms a heterogeneous mixture of distinct species, and therefore it is here simply left in open nomenclature as Paraorthacodus sp.

Superorder Galeomorphii Compagno, 1973

Order Orectolobiformes Applegate, 1972

Incertae familiae

Orectolobiformes gen. et sp. indet.

Figure $4 a-d$

Material. One complete tooth (GG 438/54).

Description. The single specimen GG $438 / 54$ is a very small, almost completely preserved tooth measuring $3.4 \mathrm{~mm}$ in total height and $3.3 \mathrm{~mm}$ in maximum width. The tooth crown is characterized by a robust and symmetrical central cusp that is approximately as high as the crown base (Fig. 4a) and flanked by a single pair of very redundant lateral cusplets with weakly developed cutting edges that are continuous with those of the central cusp (Fig. 4b-d). The labial face of the crown is slightly convex and the labial edge is evenly rounded and overhangs the root by a short and broad apron (Fig. 4d). The lingual face is strongly convex and forms a prominent, well-developed, broad but rather short lingual uvula that is wider than the central cusp (Fig. 4b, c). The tooth crown is devoid of any ornamentation.

The root is massive, rather high, and almost as wide as the crown. The vascularisation is of hemiaulacorhize type with root lobes that are labially divergent giving the root a codiform appearance in basal view. A rather large central foramen opens on the basal surface of the root where the root lobes meet. An additional pair of margino-lateral foramina is present.

Discussion. The single tooth with its robust crown forming a low principal cusp and a single pair of reduced lateral cusplets, in combination with a broad labial apron overhanging the root, the presence of a massive, $\mathrm{V}$-shaped root exhibiting the hemiaulacorhize vascularization pattern, warrants allocation within Orectolobiformes, whose stratigraphic range was previously given as Toarcian to Recent (e.g., Cappetta 2012). In consequence, the here described orectolobiform tooth represents the earliest known fossil evidence of this group of elasmobranch sharks.

The systematic interrelationships of Mesozoic orectolobiforms, however, remain ambiguous and largely unresolved due to very generalized tooth morphologies, and therefore most Jurassic genera are usually considered as incertae familiae (e.g., Underwood and Ward 2004; Rees 2010; Srdic et al. 2016). From the Toarcian, three orectolobiform species were reported, including Annea maubeugei Delsate and Thies, 1995 from the middle Toarcian of Belgium, Palaeobrachaelurus aperizostus Thies, 1983 from the upper Toarcian of Germany, and Microtoxodus gülakmani Delsate, 2003 from both the middle Toarcian of Germany and the upper Toarcian of Luxembourg. The status of Microtoxodus as a valid genus, however, should be considered provisional, because this taxon might be synonymous with Folipistrix Kriwet, 2003 from the Aalenian of Germany as already stated by Cappetta (2012). Additional Jurassic orectolobiform genera are Dorsetoscyllium Underwood and Ward, 2004, Heterophorynus Underwood and Ward, 2004, and Ornatoscyllium Underwood and Ward, 2004 from the Bathonian of England, Akaimia Rees, 2010 from the Callovian to Oxfordian of Europe, Phorcynis Thiollière, 1852 from the Kimmeridgian to Tithonian of Europe, and Palaeorectolobus Kriwet, 2008 from the Tithonian of Germany. However, a definite assignment of the here described orectolobiform tooth to any of the known Jurassic orectolobiforms is precluded due to its very generalized morphology, which otherwise displays close similarities to teeth of the extant genus Hemiscyllium Smith, 1837, whose fossil record dates back to the Cenomanian (Dingerkus and DeFino 1983; Kriwet et al. 2007). Hemiscyllium is included together with the Late Cretaceous genera Acanthoscyllium Cappetta, 1980, Almascyllium Cappetta, 1980, and Mesiteia GorjanovićKramberger, 1885, as well as the extant genus Chiloscyllium Müller and Henle, 1837, which has a fossil record extending back to the Early Cretaceous in the family Hemiscyllidae. Within this taxonomic arrangement, teeth of Acanthoscyllium and Almascyllium bear closest similarities to those of Hemiscyllium but differ in possessing an ornamented tooth crown 


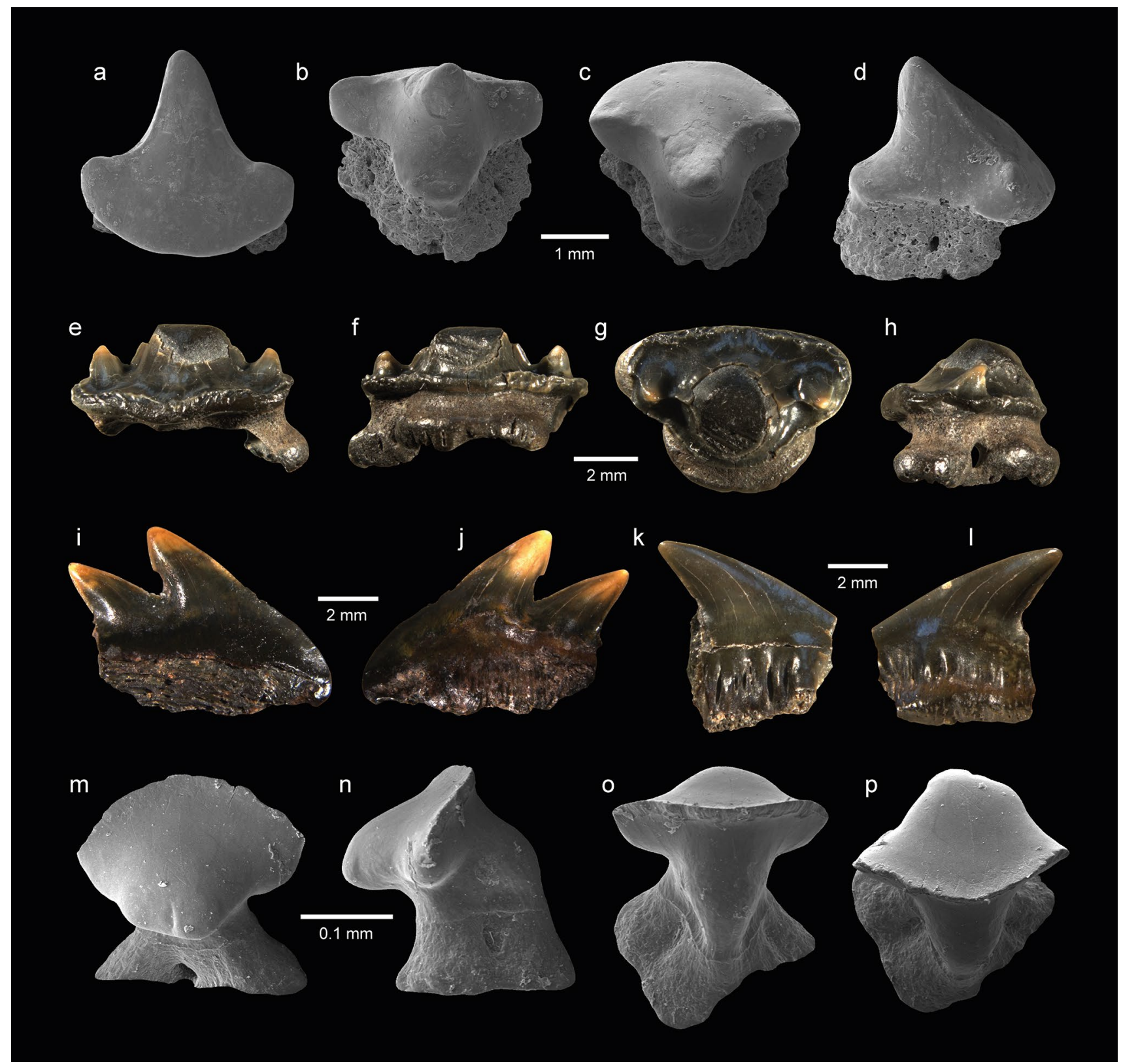

Fig. 4 Neoselachian crown-group representatives from the upper Pliensbachian of Grimmen (Mecklenburg-Western Pomerania, NE Germany). a-d Orectolobiformes gen. et sp. indet., anterior tooth (GG 438/54) in labial (a), lingual (b), occlusal (c), and (d) lateral aspects; e-h Agaleus dorsetensis Duffin and Ward, 1983, lateral tooth

(e.g., Bardet et al. 2000; Antunes and Cappetta 2002; Vullo et al. 2007), unlike the Grimmen specimen, which shares with Hemiscyllium an unornamented crown. However, the Grimmen specimen differs in the general morphology of the labial apron, which is much more developed and thinner, reaching the basal plane of the root in lateral views in Hemiscyllium and in the massiveness of the root. The character combination indicates that this specimen represents a new, previously unrecognized hemiscyllid or closely related form. However,
(438/34) in (e) labial, (f) lingual, (g) occlusal, and (h) lateral views; Notidanoides sp.; $\mathbf{i}-\mathbf{l}$ tooth (MV 202623) in labial (i) and (j) lingual views; tooth (GG 438/56) in (k) labial and (l) lingual aspects; $\mathbf{m}-\mathbf{p}$ Antiquaobatis grimmenensis gen. et sp. nov., holotype (GG 438/57) in labial (m), lateral (n), lingual (o), and (p) occlusal aspects

we refrain here from assigning it to any genus or species since the single specimen of this taxon provides insufficient taxonomic information. Consequently, specimen GG 438/54 is here referred to as Orectolobiformes gen. et sp. indet. until more material is available for study.

Incerti ordinis

Family Agalidae Rees, 2000 
Genus Agaleus Duffin and Ward, 1983

Type species. Agaleus dorsetensis Duffin and Ward, 1983 from the Hettangian-Sinemurian (Early Jurassic) of Lyme Regis, England.

Agaleus dorsetensis Duffin and Ward, 1983

Figure $4 \mathrm{e}-\mathrm{h}$

Material. Two incomplete teeth (438/34; MV 202622).

Description. The teeth are characterized by a distinct, robust and lingually inclined principal cusp with a circular crosssection. Laterally, the principal cusp is flanked by a single pair of small cusplets (Fig. $4 \mathrm{e}-\mathrm{g}$ ). The cutting edges are well-developed and continuous throughout the principal cusp and the lateral cusplets. The tooth crown is strongly demarcated from the root, forming a distinct horizontal ridge that runs along the crown base (Fig. $4 \mathrm{e}-\mathrm{h}$ ). Labially, the horizontal ridge is ornamented by a series of short, irregularly arranged folds (Fig. 4e).

The root is high, hollowed out basally, and exhibits a $\mathrm{V}$-shaped appearance in basal aspect, forming a wide and well-rounded lingual protuberance (Fig. 4g, h) and two short root lobes, with a single pair of large margino-lingual foramina (Fig. 4h). Several small, slit-like foramina are present along the lower half of the root (Fig. 4f). A central foramen could not be observed.

Discussion. The teeth can be easily assigned to Agaleus dorsetensis Duffin and Ward, 1983, an enigmatic tooth-based species, which is known exclusively from Hettangian to Pliensbachian epicontinental strata of central and western Europe (see Rees and Cuny 2007; Duffin 2010). When initially described by Duffin and Ward (1983), the authors included A. dorsetensis in Orectolobiformes without allocating it to any specific family. Later, Rees (2000) removed A. dorsetensis from Orectolobiformes and included the species in Agalidae, a new family of uncertain higher affinities, suggesting that Agalidae falls within Galeomorphii, a view that was supported by subsequent tooth histological analyses provided by Rees and Cuny (2007).

Superorder Squalomorphii Compagno, 1973

Order Hexanchiformes de Buen, 1926

Suborder Hexanchoidei Garman, 1913

Family Crassodontidanidae Kriwet and Klug, 2016

Genus Notidanoides Maisey, 1986

Type species. Notidanus muensteri Agassiz, 1843 from the Oxfordian (Late Jurassic) of Streitberg, Germany.
Notidanoides sp.

Figure 4i-1

Material. Two partially preserved teeth (GG 438/56; MV 202623).

Description. Both teeth are incomplete. The most complete specimen comprises two cusps, the main cusp and one accessory cusplet (Fig. 4i, j). The other specimen preserves only the main cusp (Fig. 4. k, l). The tooth crown is devoid of any ornamentation. The main cusp is elongated, but lacks most of the distal crown portion. A mesial heel is seemingly not developed. The root is markedly rounded basally (Fig. 4i, j). The mesial cutting edge of the main cusp is straight to slightly convex without serrations or crenulations. The distal cutting edge is straight. The main cusp is slightly higher than the first accessory cusplet and both the labial and lingual faces of the main cusp and the accessory cusplet are slightly convex.

The root is labio-lingually flattened and rather high, forming a weakly elevated lingual root bulge, which is restricted to the lower half of the root (Fig. 41). It exhibits several small, irregularly arranged foramina. Furthermore, a few vertical grooves are aligned along the upper part of the lingual root face just above the root bulge. The labial root face is penetrated by a number of vertically orientated, slit-like foramina (Fig. 4k).

Discussion. The above described teeth with their labiolingually compressed tooth morphology, together with the presence of an elongated main cusp possessing a continuous mesial cutting edge without any serrations or crenulations, resembles teeth of Notidanoides Maisey, 1986 closely, thus separating them from teeth of Crassodontidanus Kriwet and Klug, 2011, which are characterized by possessing a main cusp with a serrated mesial cutting edge. Kriwet and Klug (2016) included the European Early to Late Jurassic genera Notidanoides and Crassodontidanus, together with the European Early Cretaceous genus Pachyhexanchus Cappetta, 1990 in a new family, Crassodontidanidae, which they considered to be the most plesiomorphic taxon within Hexanchiformes.

Teeth of Pachyhexanchus are rather similar to those of Notidanoides but differ in the presence of a more prominent and even more upright main cusp forming a distinct mesial heel (Ward and Thies 1987; Cappetta 1990), thus making a positive assignment of the Grimmen teeth to Pachyhexanchus unlikely. Noteworthy, despite having previously been reported from the Early Cretaceous only, Pachyhexanchus or an even closely related form appears to have been already present by Early Jurassic times, as suggested by a single almost complete tooth recovered from the late Pliensbachian 
of southern Germany figured by Simonsen (2012: pl. 24, fig. 4).

According to Kriwet and Klug (2014), the genus Notidanoides comprises two species, $N$. arzoënsis (de Beaumont, 1960) from the Sinemurian of Switzerland, which is known from a few teeth only, and N. muensteri (Agassiz, 1843), which is represented by teeth and skeletal remains from Oxfordian to Tithonian strata of Germany, France, Spain, Switzerland, and Russia. The validity of $N$. arzoënsis, however, should be treated as provisional as this species is based on a few partially preserved teeth reminiscent to those of $N$. muensteri, and therefore $N$. arzoënsis might represent a junior subjective synonym of $N$. muensteri, as already suggested by Cappetta (1990). Teeth of N. arzoënsis and N. muensteri are characterized by rather labio-lingually robust tooth crowns compared to extant hexanchiforms, with a main cusp that is distinctly larger and more massive than the accessory cusplets. Consequently, a taxonomic assignment of the Grimmen teeth to any of the aforementioned species is rendered difficult. In addition, the tooth root in N. muensteri is rather massive forming a well-developed lingual root bulge, unlike the Grimmen teeth. Similarly, Rees (2000) reported a single, incomplete hexanchoid tooth from the Pliensbachian of southern Sweden that appears to be morphologically very similar to those from Grimmen, suggesting that the Swedish specimen and the Grimmen material might belong to a new, previously unrecognized species of Notidanoides. However, given the limited and fragmentary nature of the available material, we refrain from establishing a formal species name until more complete material comes to light.

Superorder Batomorphii Cappetta, 1980

Order Rajiformes Berg, 1940

Incertae familiae

Genus Antiquaobatis gen. nov.

Type species. Antiquaobatis grimmenensis sp. nov.

Etymology. The genus name is derived from the Latin adjective 'antiqua' meaning 'old', 'ancient', and the Latin noun 'batis' meaning 'ray'.

Diagnosis. Rajiform ray known from a single tooth only showing the following unique combination of morphological characters: crown-root junction not incised; neck collar broad; transverse crest wide, convex, and well-developed; no central cusp and no lateral cusplets; well-developed labial, not basally inclined apron with broad anterior margin present jutting out horizontally above the root; median lingual uvula short, narrow, low, and not overhanging the root; no lateral uvulae; tooth crown ornamentation restricted to the lowermost part of the neck collar; root massive and not lingually displaced with holaulacorhize vascularization pattern and flaring root lobes; lobes broad and V-shaped in labial view; labial and lingual root face vertical and straight; deep central and narrow nutritive groove; one pair of margino-lingual foramina.

Antiquaobatis grimmenensis gen. et sp. nov.

Figure $4 \mathrm{~m}-\mathrm{p}$

Etymology. The species name is derived from the name of the type locality, Grimmen.

Diagnosis. As for genus (by monotypy).

Holotype. One almost complete tooth (GG 438/57).

Locality. Abandoned open-cast clay pit of Grimmen (Mecklenburg-Western Pomerania, Germany).

Age. Apyrenum subzone (spinatum zone, late Pliensbachian, Early Jurassic).

Description. Antiquaobatis grimmenensis gen. et sp. nov. is represented by a very small and slightly asymmetrical, almost complete presumed antero-lateral tooth measuring $0.25 \mathrm{~mm}$ in maximum height and $0.26 \mathrm{~mm}$ in maximum width. The tooth crown is slightly wider mesio-distally than long labio-lingually, with a conspicuous, laterally extended transverse crest without a central cusp (Fig. 4m, o). The transverse crest is very convex and very sharp, giving the crown a dome-like appearance in labial view, with some irregularities along its length (Fig. $4 \mathrm{~m}, \mathrm{n}$ ), probably due to post-mortem damage. In occlusal view, the transverse cutting crest is concave labially, dividing the crown into a broad, roughly triangular labial and a very reduced labial area. The labial crown face is sigmoiodal in lateral views with a concavity directly below the cutting edge (Fig. $4 \mathrm{~m}$ ). The lingual crown face is very sigmoidal in lateral views with a marked bulge at the level of the short lingual uvula.

The lateral angles of the crown are abrupt. The crown continues labially into a broad, well-developed labial protuberance or apron. The labial protuberance strongly overhangs the root but is not basally inclined (Fig. 4n). The lingual face continues into an elongated and rather low central uvula that does not overhang the neck collar (Fig. 4n). The lingual margin of the uvula is very steep in lateral views. Additional lateral uvulae are absent. The crown-root junction is not incised. There is a high and well-developed neck collar. Tooth crown is almost entirely devoid of ornamentation, except for the lowermost part of the neck collar, where fine and closely spaced furrows are visible (Fig. $4 \mathrm{~m}-$ p).

The root is stout with basally flaring root lobes that do not extend laterally beyond the crown in occlusal view. 
Additionally, it is not lingually displaced. The root vascularization is of the holaulacorhize pattern with a deep, narrow central groove dividing the basal root face into two lobes, which are wide at their bases to give the root a somewhat V-shaped appearance in labial view. In lingual view, the root lobes also are V-shaped. The labial and lingual faces of the root are vertical and straight in mesio-distal views. The lingual root face is damaged. The root exhibits a pair of rather large, oval margino-lingual foramina.

Discussion. The overall morphology of the single tooth, in particular the stoutly built and basally flared root exhibiting the holaulacorhize vascularization pattern, in combination with the presence of a rather robust and mesio-distally broad crown forming a distinct transverse crest, is consistent with referral to Batomorphii, which forms a speciose and ecomorphologically distinctive group of elasmobranch fishes encompassing all skates and rays. The oldest fossil records attributable to Batomorphii are from the European late Early Jurassic, including Toarcibatis Delsate and Candoni, 2001, Cristabatis Delsate and Candoni, 2001, and Doliobatis Delsate and Candoni, 2001, which were based on isolated dental material from the Toarcian of France, Belgium, and Luxembourg, and grouped together within the family Archaeobatidae. 'Spathobatis' moorbergensis Thies, 1983, based on teeth from the upper Toarcian of northern Germany, represents the currently oldest known fossil record of 'Rhinobatoidea'. Teeth of Archaeobatidae as well as those of 'Spathobatis' moorbergensis are easily distinguishable from teeth of Antiquaobatis grimmenensis gen. et sp. nov., particularly by robust, low, and transversally wide tooth morphologies indicating effective crushing type dentitions.

By the Middle and Late Jurassic, batomorphs seemingly became more abundant reaching a cosmopolitan distribution by the Tithonian (e.g., Cavin et al. 1995; Cione 1999; Arratia et al. 2002; Underwood and Ward 2004; Cuny et al. 2008, 2009), and six valid genera currently are recognized for the Middle to Late Jurassic time interval, including Belemnobatis Thiollière, 1852, Spathobatis Thiollière, 1852, Asterodermus Agassiz, 1843, Engaibatis Arratia, Kriwet, and Heinrich, 2002, Leiribatos Kriwet, 2004, and Kimmerobatis Underwood and Claeson, 2017. Of these, the tooth-based taxa Engaibatis and Leiribatos cannot be referred to any existing family and are left within Rajiformes as incertae familiae. The genera Belemnobatis, Spathobatis, and Asterodermus, which are known by both dental and skeletal material, generally are assigned to the extant family Rhinobatidae (e.g., Cavin et al. 1995; Cappetta 1987, 2012; Thies and Leidner, 2011). Underwood and Claeson (2017), however, recently rejected this arrangement based on a phylogenetic analysis, in which their new genus Kimmerobatis was recovered to form part of a separate family, together with Belemnobatis and Spathobatis. The precise systematic position of Asterodermus remains unresolved, and a re-evaluation of the type material from the Tithonian of southern Germany is needed in order to validate its systematic affinities (see Rees 2005; Klug and Kriwet 2013 for discussion).

Teeth of Belemnobatis and Spathobatis show some morphological resemblance to those of Protospinax Woodward, 1919, a speciose but still problematic squalomorph shark from the Jurassic and Cretaceous of Europe (see de Carvalho and Maisey 1996; Klug and Kriwet 2013; Guinot et al. 2014). Teeth traditionally referred to Protospinax are generally characterized by lingually displaced roots, a feature shared with Belemnobatis and Spathobatis, thus readily separating them from Antiquaobatis grimmenensis gen. et sp. nov.

The tooth morphology of Antiquaobatis grimmenensis gen. et sp. nov. indicates closest affinities to the monotypic genus Engaibatis schultzei from the Kimmeridgian-Tithonian of Tanzania in both crown and root morphology. Notably, both species are characterized by rather gracile tooth crown morphology, separating them from most other described Jurassic batomorphs, which typically possess more robust and transversally wide crowns. However, the absence of a central cusp as well as additional lateral cusplets, combined with the presence of a prominent labial protuberance, the possession of an elongated but rather low central lingual uvula that does not overhang the neck collar, and the presence of a more stoutly built and not lingually displaced root, clearly distinguishes Antiquaobatis grimmenensis gen. et sp. nov. from teeth of E. schultzei.

Antiquaobatis grimmenensis gen. et sp. nov. represents the oldest unequivocally identified fossil record of Batomorphii and it is left here as Rajiformes incertae familiae until the systematics and interrelationships of Jurassic batomorphs are fully resolved.

The erection of a new elasmobranch taxon based on a single isolated tooth is certainly not straightforward and in most cases not favorable, particularly because dental features related to heterodonty are non-determinable. Nevertheless, it is evident that the tooth of Antiquaobatis grimmenensis gen. et sp. nov. is distinct from those of all other known batomorphs in displaying a unique combination of morphological characters, thus justifying the introduction of a new genus and species.

\section{Discussion}

\section{Taphonomy}

The here described elasmobranch dental material from the sandy, marginal marine upper Pliensbachian of Grimmen is considered to be largely of allochthonous origin, as it has suffered massively from post-mortem breakage in many 
cases, most probably due to extensive reworking and redistribution generated by current activities. Therefore, the here reported taxa might have inhabited marine areas that were located in closer proximity to the Fennoscandian mainland, such as the paralic depositional environments referred to the late Pliensbachian to early Aalenian Sorthat Formation of Bornholm, Denmark (see Michelsen et al. 2003; Vajda and Wigforss-Lange 2009). In addition, some teeth have been affected by bioerosion, as confirmed by microborings attributable to the ichnospecies Mycelites ossifragus Roux, 1887 (see Underwood and Mitchell 1999; Underwood et al. 1999; Underwood and Rees 2002), suggesting that the material was exposed on the sea-floor for long periods of time before burial. The causative organism of these structures, however, remains obscure, although an attribution to endolithic fungi and/or algae appears most likely.

\section{Palaeoecology}

Elasmobranch teeth are of high taxonomic value and also offer significant adaptive features for inferring possible diet preferences (Cappetta 2012). However, as shown by Whitenack and Motta (2010), tooth morphologies alone provide only a broad idea about their actual biological roles. Therefore, the diet preferences addressed below should be treated with caution, as the proposed prey ranges were most probably more diverse than expected when it comes to tooth morphologies alone.

As revealed by the fossil record, Hybodus formed a common and widely distributed component within the marine Early Jurassic marine ecosystems, ranging from the Hettangian to the Toarcian (e.g., Delsate and Duffin 1993; Duffin 1997, 2010; Rees 1998; Delsate et al. 2002). The teeth of Hybodus reticulatus and $H$. hauffianus correspond to the clutching-type, which infer a diet predominantly composed of cephalopods but also fish. The former is confirmed by about 250 belemnite rostra that were found preserved as stomach contents in a unique holomorphic specimen of $H$. hauffianus from the Toarcian of southern Germany (Schmidt 1921).

The hybodontiform genus Lissodus seems to have been rather limited in its facies distribution (Rees 1998, 2001), being represented by at least two separate species within the Pliensbachian marginal marine ecosystems south of Fennoscandia (Rees 1998; this contribution). Notably, the scarcity of Lissodus in open marine, offshore environments, combined with the high abundance of Lissodus teeth in the marginal marine, near-shore Hasle Formation of Bornholm (Rees 1998), might reflect a palaeobiogeographic segregation amongst European Early Jurassic hybodontiforms, probably in response to specific ecological and/or biological constraints, but more likely corresponds to sampling biases (Rees 1998). Lissodus is characterized by teeth that correspond to the grasping-crushing type suitable for crushing soft- to hard-shelled food items, suggesting that this taxon predominantly fed on benthic invertebrates (Rees and Underwood 2002).

The here reported indeterminate lonchidiid tooth indicates close architectural resemblance to Parvodus, whose teeth refer to the cutting-crushing type (Rees and Underwood 2002). This might suggests that the Grimmen lonchidiid fed on different prey species as compared to Lissodus, probably in order to partition available niche spaces efficiently, but more material is needed in order to assess dental features related to heterodonty and potential feeding habits in the former taxon.

The synechodontiform genera Palidiplospinax, Paraorthacodus, and Sphenodus probably were benthopelagic sharks predominantly bound to marginal marine waters (Thies and Reif 1985; Underwood 2004; Klug et al. 2009). Like Synechodus, Palidiplospinax is characterized by a clutching- to tearing-type dentition similar to that in extant scyliorhinids (Duffin and Ward 1993; Klug and Kriwet 2008), suggesting a wide range of prey preferences including fish, soft-bodied invertebrates, and crustaceans. The dentition of Paraorthacodus is more specialized towards the tearing-type (Klug et al. 2009), a condition strongly expressed in Sphenodus (Böttcher and Duffin 2000), suggesting that both taxa were mobile predatory sharks predominantly feeding on fast swimming animals like fish and squid.

Hexanchiform sharks appear to have been rather rare during Early Jurassic times (Kriwet and Klug 2011), which might suggest that they inhabited open or deeper water areas on outer continental shelves and slopes similar to most extant hexanchiforms (e.g., Barnett et al. 2012). Notidanoides is known to have formed a strong cutting dentition (Kriwet and Klug 2014) adapted to cut tough prey materials. Likewise, pseudonotidanid synechodontiforms also are characterized by strong cutting-type dentitions (e.g., Underwood and Ward 2004; Klug and Kriwet 2010), suggesting similar feeding habits. The oldest fossil records referred to Pseudonotidanidae are Pseudonotidanus politus (Thies, 1992) from the Toarcian of Germany and Welcommia terencei Delsate and Godefroit, 1995 from the lower Toarcian of Belgium. The latter genus, however, is already present by pre-Toarcian times, as exemplified by isolated teeth of a yet undetermined species from the lower Pliensbachian of northeastern France figured by Delsate (2001: pl. 1, figs. N-Q), who erroneously referred the material to Hexanchidae indet.

The monotypic genus Agaleus is one of the most common and widely distributed European Early Jurassic elasmobranchs. Its rather robust dentition (e.g., Rees and Cuny 2007), which corresponds to the clutching-type, together with its wide palaeobiogeographical distribution, suggests that Agaleus was a benthopelagic shark with a diet of various thin- to hard-shelled invertebrates. 
The here reported indeterminate orectolobiform tooth indicates close morphological resemblance to Hemiscyllidae, which might suggests that orectolobiform sharks with similar life styles and adaptations might have been already present by Early Jurassic times. Extant members of Hemiscyllidae are small, nocturnally active nectobenthic sharks with restricted habitat distributions towards shallow marine, near-shore environments, such as coral reefs and seagrass flats (Compagno 2001; Allen et al. 2016). Hemiscyllid teeth are rather unspecialized, which corresponds to a wide range of prey preferences, including fish, soft-bodied invertebrates, as well as shelled molluscs and crustaceans (e.g., Heupel and Bennett 1998).

A nectobenthic lifestyle has been also suggested for Jurassic batomorphs (e.g., Thies and Reif 1985; Underwood 2004; Klug and Kriwet 2013), in particular for taxa known from complete skeletons such as Belemnobatis and Spathobatis, which are generally characterized by sharing a bauplan similar to extant rhinobatids, with an elongated rostrum, dorso-ventrally flattened body with enlarged pectoral fins, and a muscular tail. Corresponding to the crushing-type, the dentitions of these taxa are composed of small, massive, and densely arranged teeth, inferring specialized feeding adaptations towards hard-shelled prey. Likewise, similar feeding habits might have been typical for archaeobatids, as their teeth are generally characterized by massive and transversally broad tooth morphologies (Delsate and Candoni 2001). Conversely, Antiquaobatis grimmenensis gen. et sp. nov. appears to have used different, less specialized and probably more opportunistic feeding strategies, as suggested by the gracile and high tooth morphology, but more material is needed in order to assess possible feeding habits in Antiquaobatis grimmenensis gen. et sp. nov. more properly.

\section{Late Early Jurassic diversity and distributional patterns}

Occurrences of Early Jurassic elasmobranchs are almost exclusively known from Europe, where numerous chondrichthyan-bearing localities have been reported since the 19th century (e.g., Charlesworth 1839; de Beaumont 1960; Thies 1983; Delsate et al. 1989; Delsate and Duffin, 1993; Duffin 1993, 1997, 2010; Delsate and Godefroit 1995; Rees 1998, 2000; Delsate and Candoni 2001; Delsate et al. 2002; Vincent et al. 2013; Romano et al. 2018). However, although the knowledge of Early Jurassic cartilaginous fishes has expanded substantially in recent decades, our understanding of their distributional patterns remains very heterogenous. This is mainly because the great majority of reported Early Jurassic elasmobranch occurrences come from open marine, offshore settings, while material from marginal marine, near-shore depositional environments remains very rare due to the scarcity of productive localities to date.

The taxonomic diversity and distribution patterns of Early Jurassic elasmobranchs thus are strongly biased towards open marine, offshore environments, rendering the study of their macroevolutionary patterns and processes difficult (Underwood 2004, 2006). So far, the Danish island of Bornholm in the Baltic Sea is the only European place known to have produced Early Jurassic cartilaginous fish remains of marginal marine origin, including those of hybodontiforms, neoselachians, and holocephalians (Rees 1998; Duffin and Milàn 2017). These are derived from the Hasle Formation, a fine-grained sandstone to coarse-grained siltstone of early Pliensbachian age that was deposited in close proximity to the Fennoscandian Shield (see Vajda and Wigforss-Lange 2009). The here reported fossil assemblage from the upper Pliensbachian of Grimmen, therefore, offers a rare glimpse into the taxonomic diversity of marginal marine Early Jurassic elasmobranchs, revealing the presence of a diverse fauna in the marginal marine ecosystems south of Fennoscandia immediately before intense global palaeoenvironmental perturbation episodes that occurred at and immediately following the Pliensbachian-Toarcian transition. The faunal composition of the here described fossil assemblage indicates close affinities to other pre-Toarcian elasmobranch assemblages, which are usually composed of hybodontiforms, synechodontiforms, hexanchiforms, and Agaleus (e.g., Biddle 1993; Rees 1998, 2000; Delsate et al. 2002; Duffin 2010). By the Toarcian, orectolobiforms (e.g., Annea Thies, 1983, Palaeobrachaelurus Thies, 1983) and heterodontiforms (e.g., Paracestracion Koken in von Zittel, 1911) as well as batomorphs (mainly represented by archaeobatids) became abundant for the first time (Fig. 5), resulting in a first major neoselachian diversification event (Kriwet et al. 2009; Guinot et al. 2012; Guinot and Cavin 2016), probably accompanied by a sudden and nearly simultaneous colonization of a wide range of marine environments and subsequent reorganization of ecological niches of elasmobranchs (Underwood 2004, 2006). Obviously, the here presented fossil evidence of both Orectolobiformes and Batomorphii from late Pliensbachian marginal marine, near-shore facies provide some support for the hypothesis by Underwood (2004, 2006) that most neoselachian crown-group representatives were initially linked to marginal marine, near-shore environments, before moving into open marine, offshore habitats by the Toarcian, thus providing promising clues for better understanding Early Jurassic chondrichthyan diversity and distributional patterns.

Potential causes underlying the Toarcian neoselachian diversification event include diverse factors, such as evolutionary novelties in ecological adaptations of feeding and reproduction (Thies and Reif 1985; Kriwet et al. 2009), but environmental changes such as the early Toarcian 


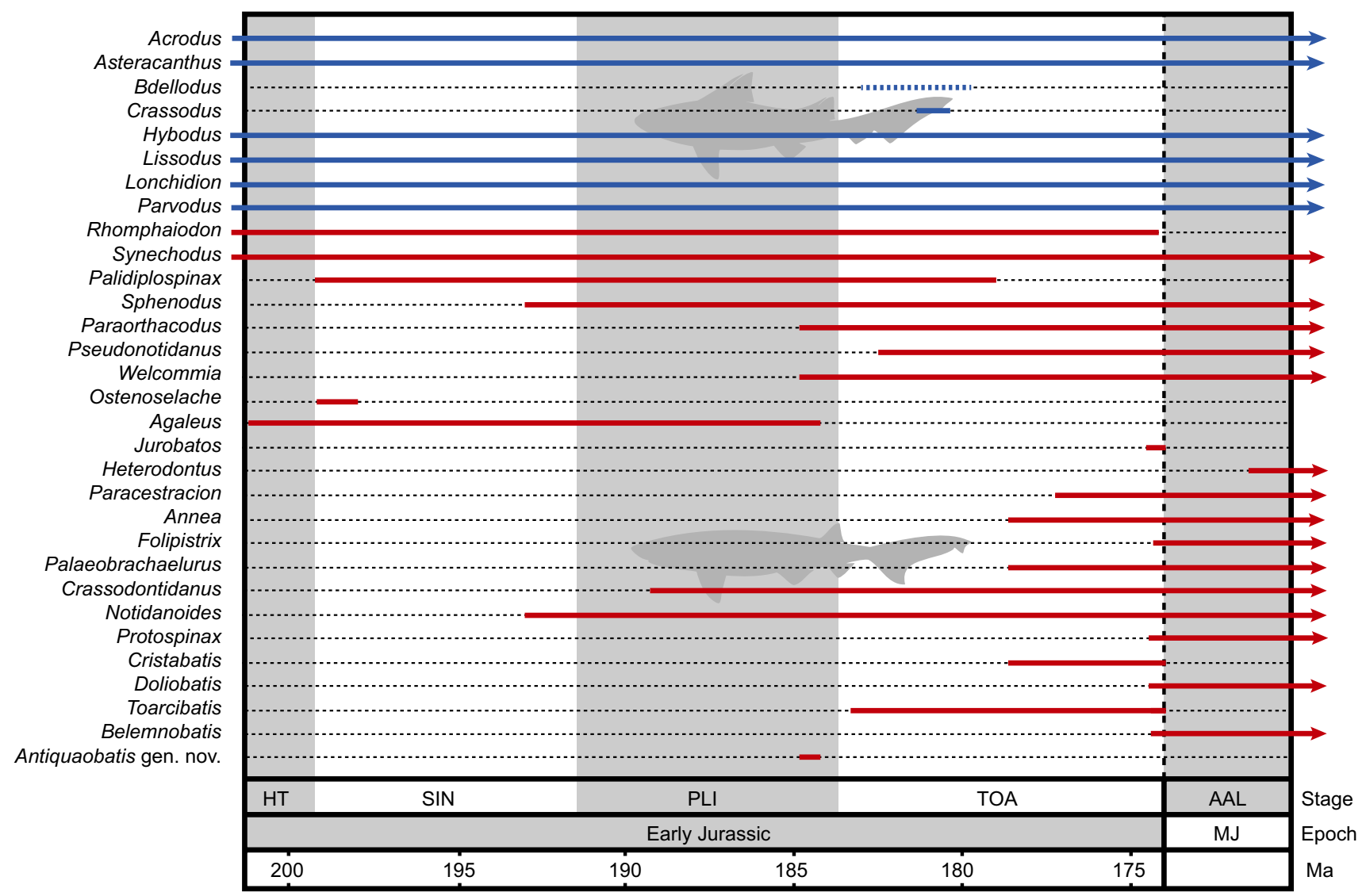

Fig. 5 Chart illustrating the stratigraphic distribution of Early to early Middle Jurassic (Aalenian) hybodontiform and neoselachian fishes (hybodontiforms are indicated in blue and neoselachians in red).

transgression might also have favored diversification by providing enlarged epicontinental environments suitable for dispersal and speciation (Kriwet et al. 2009; Guinot and Cavin 2016). In addition, as there is a constantly growing body of evidence that temperature is one of the main determinants controlling global biodiversity patterns (e.g., Allen et al. 2006; Wright et al. 2006, 2011; Tittensor et al. 2010; Belmaker and Jetz 2011), increasing seawater temperatures associated with the T-OAE might also have played a role in the Toarcian neoselachian radiation event by generating higher speciation rates (Guinot and Cavin 2016). In addition, Thies and Reif (1985) proposed that the radiation of neoselachians was opportunistic, probably in response to the rapid diversification of new food resources, such as teleosts from the Early Jurassic onwards (e.g., López-Arbarello and Sferco 2018).

Jurassic hybodontiform sharks are generally assumed to have been negatively affected by the radiation of Jurassic neoselachians due to increasing competition, resulting in a diversity decline towards the end of the Jurassic and subsequent displacement towards continental waters by the Early Cretaceous onwards (e.g., Thies and Reif 1985; Rees
Timescale based on Ogg et al. 2016. AAL Aalenian, HT Hettangian, PLI, Pliensbachian, SIN Sinemurian, TOA Toarcian

and Underwood 2008; Cuny 2012; Leuzinger et al. 2017). Notably, late Early Jurassic hybodontiform sharks seem to have been unaffected by the radiation of neoselachians (Fig. 5), which might suggest that both groups occupied different niche spaces in order to partition the available food resources efficiently, but more research is needed for evaluation of this hypothesis. For instance, the generic content of Jurassic hybodontiforms still remains ambiguous and unresolved (e.g., Maisey 1987; Rees and Underwood 2008; Rees 2008; Maisch and Matzke 2016), pending further taxonomic research.

\section{Conclusion}

Although being based on rare and fragmentary material, the results derived from the present study provide new insights into the taxonomic and ecological diversity of Pliensbachian elasmobranchs, and also contribute to our current knowledge about late Early Jurassic elasmobranch distributional patterns. Nevertheless, many taxa, especially hybodontiform 
sharks, are still in need of revision, therefore more taxonomic research is required in order to gain deeper insights into Early Jurassic elasmobranch life.

Acknowledgements Open access funding provided by University of Vienna. Stefan Meng (GG) and Karsten Obst (MV) are thanked for providing access to the collections in their care, and Rabea Schlüter and Stefan Bock (both Department of Biology, University of Greifswald) for helping with the SEM imaging. Thanks are also due to Jörg Ansorge, Bernd Röber, and Hannes Löser for providing information regarding the specimens they have collected. We are grateful to Christopher Duffin (Surrey, UK) and Charlie Underwood (London, UK) as well as Editor-in-Chief Mike Reich (Munich, Germany) for their constructive suggestions that improved the manuscript. This is a contribution of the IGCP 655 (IUGS-UNESCO)

Open Access This article is distributed under the terms of the Creative Commons Attribution 4.0 International License (http://creativeco mmons.org/licenses/by/4.0/), which permits unrestricted use, distribution, and reproduction in any medium, provided you give appropriate credit to the original author(s) and the source, provide a link to the Creative Commons license, and indicate if changes were made.

\section{References}

Adolfssen, J.S., and D.J. Ward. 2014. Crossing the boundary: an elasmobranch fauna from Stevns Klint, Denmark. Palaeontology 57: 591-629.

Agassiz, L.J.R. 1833-1844. Recherches sur les Poissons fossils. Neuchâtel: Petitpierre, in 5 vols.

Allen, A.P., J.F. Gillooly, V.M. Savage, and J.H. Brown. 2006. Kinetic effects of temperature on rates of genetic divergence and speciation. Proceedings of the National Academy of Sciences USA 103: 9130-9135.

Allen, G.R., M.V. Erdmann, W.T. White, Fahmi, and C.L. Dudgeon. 2016. Review of the bamboo shark genus Hemiscyllium (Orectolobiformes: hemiscyllidae). Journal of the Ocean Science Foundation 23: 51-97.

Ansorge, J. 2007. Lower Jurassic clay pit of Klein Lehmhagen near Grimmen. In Geo-Pomerania-Excursion guide, eds. R.-O. Niedermeyer, R. Dobracki, and K. Schütze, 37-41. (=Biuletyn Państowowego Instytutu Geologicznego 424).

Ansorge, J., and K. Obst. 2015. Lias-Tongrube bei Dobbertin. In 79. Tagung der Arbeitsgemeinschaft Norddeutscher Geologen Tagungsband und Exkursionsführer, eds. A. Börner, R.-O. Niedermeyer, and K. Schütze, 227-240. (=Schriftenreihe des Landesamtes für Umwelt, Naturschutz und Geologie Mecklenburg-Vorpommern 1).

Antunes, M.T., and H. Cappetta. 2002. Sélaciens du Crétacé (AlbienMaastrichtien d'Angola). Palaeontographica, Abteilung A 264: 85-146.

Applegate, S.P. 1972. A revision of the higher taxa of orectolobids. Journal of the Marine Biological Association of India 14: 743-751.

Arratia, G., J. Kriwet, and W.-D. Heinrich. 2002. Selachians and actinopterygians from the Upper Jurassic of Tendaguru, Tanzania. Mitteilungen des Museums für Naturkunde Berlin, Geowissenschaftliche Reihe 5: 207-230.

Bailey, T.R., Y. Rosenthal, J.M. McArthur, B. van de Schootbrugge, and M.F. Thirwall. 2003. Paleoceanographic changes of the late Pliensbachian-early Toarcian interval: a possible link to the genesis of an Oceanic Anoxic Event. Earth and Planetary Science Letters 212: 307-320.

Bardet, N., H. Cappetta, X.P. Suberbiola, and M. Mouty. 2000. The marine vertebrate faunas from the Late Cretaceous phosphates of Syria. Geological Magazine 137: 269-290.

Barnett, A., J.M. Braccini, C.A. Awruch, and D.A. Ebert. 2012. An overview on the role of Hexanchiformes in marine ecosystems: biology, ecology and conservation status of a primitive order of modern sharks. Journal of Fish Biology 80: 966-990.

Beaumont, G. de. 1960. Contribution à l'étude des genres Orthacodus Woodw. et Notidanus Cuv. (Selachii). Mémoires Suisses de Paléontologie 77: 1-46.

Belmaker, J., and W. Jetz. 2011. Cross-scale variation in species richness-environment associations. Global Ecology and Biogeography 20: 464-474.

Berg, L.S. 1940. [Classification of fishes, both recent and fossil.] Transactions of the Institute of Zoology, Academy of Sciences USSR 5: 85-517. [in Russian].

Bermúdez-Rochas, D.D. 2009. New hybodont shark assemblage from the Early Cretaceous of the Basque-Cantabrian Basin. Geobios 42: 675-686.

Biddle, J.-P. 1993. Quelques élasmobranches du Domérien (Jurassique inférieur) de la région du Mans (Sarthe, France). Cossmanniana 2: 61-66.

Bonaparte, C.L. 1838. Synopsis vertebratorum systematis. Nuovi Annali delle Scienze Naturali Bologna 2: 105-133.

Böttcher, R., and C.J. Duffin. 2000. The neoselachian shark Sphenodus from the Late Kimmeridgian (Late Jurassic) of Nusplingen and Egesheim (Baden-Württemberg, Germany). Stuttgarter Beiträge zur Naturkunde, Serie B 283: 1-31.

Buchholz, A. 2012. Das Domerium im Lias-Aufschluss des Tontagebaues von Klein Lehmhagen bei Grimmen/Vorpommern (Nordostdeutschland). Ein Überblick. Mitteilungen der Naturforschenden Gesellschaft Mecklenburg 12: 3-20.

Buen, F. de. 1926. Catálogo ictiológico del Mediterráneo espanol y de Marruecos recopilando lo publicado sobre peces de las costas mediterránea y próximas del Atlántico (Mar de Espana). Commission Internationale pour l'exploration scientifique de la mer Méderiterranée, Madrid 2: 1-221.

Cappetta, H. 1980. Les sélaciens du Crétacé supérieur du Liban. II. Batoides. Palaeontographica, Abteilung A 168: 149-229.

Cappetta, H., 1987. Handbook of Paleoichthyology, Vol. 3B: Chondrichthyes II. Stuttgart: Gustav Fischer Verlag.

Cappetta, H. 1990. Hexanchiforme nouveau (Neoselachii) du Crétacé inférieur du sud de la France. Palaeovertebrata 20: 33-54.

Cappetta, H. 2012. Chondrichthyes: Mesozoic and Cenozoic Elasmobranchii. Handbook of Paleoichthyology, 3E. Munich: Verlag Dr. Friedrich Pfeil.

Caruthers, A.H., P.L. Smith, D.R., and D.R. Gröcke. 2014. The Pliensbachian-Toarcian (Early Jurassic) extinction: A North American perspective. In Volcanism, Impacts, and Mass Extinctions: Causes and Effects, eds. G. Keller, and A.C. Kerr, 225-243. (=Geological Society of America, Special Paper 505).

Carvalho, M.R. de, and J.G. Maisey. 1996. The phylogenetic relationships of the Late Jurassic shark Protospinax Woodward, 1919 (Chondrichthyes: Elasmobranchii). In Mesozoic fishes-systematics and paleoecology, eds. G. Arratia and A. Tintori, 9-46. Munich: Verlag Dr. Friedrich Pfeil.

Caswell, B.A., A.L. Coe, and A.S. Cohen. 2009. New range data for marine invertebrate species across the early Toarcian (Early Jurassic) mass extinction. Journal of the Geological Society 166: 859-872.

Cavin, L., H. Cappetta, and B. Séret. 1995. Révision de Belemnobatis morinicus (Sauvage, 1873) du Portlandien du Boullonnais 
(Pas-de-Calais, France). Geologica et Palaeontologica 29: 245-267.

Cecca, F., and F. Macchioni. 2004. The two Early Toarcian (Early Jurassic) extinction events in ammonoids. Lethaia 37: 35-56.

Charlesworth, E. 1839. On the fossil remains of Hybodus, from Lyme Regis. The Magazine of Natural History 3: 242-248.

Cione, A.L. 1999. First report of a Jurassic ray outside of Europe. In Mesozoic Fishes 2-systematics and fossil record, eds. G. Arratia and H.-P. Schultze, 21-28. Munich: Verlag Dr. Friedrich Pfeil.

Coates, M.I., and R.W. Gees. 2007. A new reconstruction of Onychoselache traquairi, comments on early chondrichthyan pectoral girdles and hybodontiform phylogeny. Palaeontology 50: $1421-1446$

Compagno, L.J.V. 1973. Interrelationships of living elasmobranches. In Interrelationships of Fishes, eds. P.H. Greenwood, R.S. Miles, and C. Patterson, 15-61. Zoological Journal of Linnean Society 53 (Supplement 1).

Compagno, L.J.V. 1977. Phyletic relationships of living sharks and rays. American Zoologist 17: 303-322.

Compagno, L.J.V. 2001. Sharks of the World. An annotated and illustrated catalogue of shark species known to date. Volume 2. Bullhead, mackerel and carpet sharks (Heterodontiformes, Lamniformes and Orectolobiformes). FAO Species Catalogue for Fishery Purposes 1(2): 1-269.

Compagno, L.J.V., M. Dando, and S. Fowler. 2005. A field guide to the sharks of the world. London: HarperCollins.

Cuny, G. 2012. Freshwater hybodont sharks in Early Cretaceous ecosystems: a review. In Bernissart dinosaurs and Early Cretaceous terrestrial ecosystems, ed. P. Godefroit, 518-529. Bloomington: Indiana University Press.

Cuny, G., J. Rees, J. Pouech, P. Srisuk, J.-M. Mazin, and V. Suteethorn. 2008. Belemnobatis from Thailand and Cherves-de-Cognac (France): Radiation of primitive batoids during the Mesozoic. Documents des Laboratoires de Géologie Lyon 164: 33-36.

Cuny, G., P. Srisuk, S. Khamha, V. Suteethorn, and H. Tong. 2009. A new elasmobranch fauna from the Middle Jurassic of southern Thailand. In Late Palaeozoic and Mesozoic Ecosystems in SE Asia, eds. E. Buffetaut, G. Cuny, J. Le Loeuff, and V. Suteethorn, 97-113. (=The Geological Society of London, Special Publications 315).

Delsate, D. 2001. L'ichthyofaune du Pliensbachien (Jurassique inférieur de Lorraine et des Ardennes (France): premiers résultats. Bulletin de l'Académie Lorraine des Sciences 40: 47-69.

Delsate, D. 2003. Une nouvelle faune de poissons et requins toarciens du sud du Luxembourg (Dudelange) et de l'Allemagne (Schömberg). Bulletin de l'Académie Lorraine des Sciences 42: 13-49.

Delsate, D., and L. Candoni. 2001. Description de nouveaux morphotypes dentaires de Batomorphii toarciens (Jurassique inférieur) du Bassin de Paris Archaeobatidae nov. fam. Bulletin de la Société des Naturalistes Luxembourgeois 102: 131-143.

Delsate, D., and C.J. Duffin. 1993. Chondrichthyens du Sinémurien de Belgique. Belgian Geological Survey, Professional Paper 264: 103-136.

Delsate, D., and P. Godefroit. 1995. Chondrichthyens du Toarcien inférieur d'Aubange (Lorraine beige). Belgian Geological Survey, Professional Paper 278: 23-43.

Delsate, D., and L.-C. Lepage. 1990. Decouverte d'une faune originale d'elasmobranches dans les phosphates du Toarcien Lorrain (couche a Coeloceras crassum). Bulletin de l'Académie et Société lorraines des Sciences 29: 153-161.

Delsate, D., and L.-C. Lepage. 1993. Selaciens du Trias et du Jurassique de Lorrain. Centre de Recherches Lorraines. a.s.b.l 1: 25-35.

Delsate, D., and D. Thies. 1995. Teeth of the fossil shark Annea Thies 1983 (Elasmobranchii, Neoselachii) from the Toarcian of
Belgium. Belgian Geological Survey, Professional Paper 278: 45-64.

Delsate, D., C.J. Duffin, and R. Weis. 2002. A new microvertebrate fauna from the Middle Hettangian (Early Jurassic) of Fontenoille (Province of Luxembourg, south Belgium). Memoirs of the Geological Survey of Belgium 48: 3-84.

Delsate, D., J. Herman, and J.-C. Lepage. 1989. Nouvelles faunes d'élasmobranches du Toarcien de la Lorraine Belge. Bulletin de la Société Belge de Géologie 98: 77-80.

Dera, G., P. Neige, J.-L. Dommergues, E. Fara, R. Laffont, and P. Pellenard. 2010. High-resolution dynamics of Early Jurassic marine extinctions: the case of Pliensbachian-Toarcian ammonites (Cephalopoda). Journal of the Geological Society, London 167: 21-33.

Dingerkus, G., and T. DeFino. 1983. A revision of the orectolobiform shark family Hemiscyllidae (Chondrichthyes, Selachii). Bulletin of the American Museum of Natural History 176: 1-93.

Duffin, C.J. 1985. Revision of the hybodont selachian genus Lissodus Brough (1935). Palaeontographica, Abteilung A 188: 105-152.

Duffin, C.J. 1993. Teeth of Hybodus (Selachii) from the Early Jurassic of Lyme Regis, Dorset (southern England): preliminary note. Belgian Geological Survey, Professional Paper 264: 45-52.

Duffin, C.J. 1997. The dentition of Hybodus hauffianus Fraas, 1895 (Toarcian, Early Jurassic). Stuttgarter Beiträge zur Naturkunde, Serie B 256: 1-20.

Duffin, C.J. 2010. Chondrichthyes. In Fossils from the Lower Lias of the Dorset Coast, eds. A.R. Lord and P.G. Davis, 317-340. London: Paleontological Association.

Duffin, C.J., and D.J. Ward. 1983. Teeth of a new neoselachian shark from the British Lower Jurassic. Palaeontology 26: 839-844.

Duffin, C.J., and J. Milàn. 2017. A new myriacanthid holocephalian from the Early Jurassic of Denmark. Bulletin of the Geological Society of Denmark 65: 161-170.

Duffin, C.J., and D.J. Ward. 1993. The Early Jurassic palaeospinacid sharks of Lyme Regis, southern England. Belgian Geological Survey, Professional Paper 264: 53-102.

Ernst, W. 1967. Die Liastongrube Grimmen. Makrofauna und Stratigraphie. Ein Überblick. Geologie 16: 550-569.

Ernst, W. 1991. Der Lias im Ton-Tagebau bei Grimmen (Vorpommern). Fundgrube 27: 171-183.

Ernst, W. 1992. Der Lias der Scholle von Dobbertin (Mecklenburg). Fundgrube 28: 56-70.

Fowler, H.W. 1947. New taxonomic names of fish-like vertebrates. Notulae Naturae 187: 1-16.

Fraas, E. 1895. Ein Fund von Skelettresten von Hybodus (Hybodus Hauffianus E. Fraas). Jahresbericht und Mitteilungen des Oberrheinischen Geologischen Vereins 28: 24-26.

Fraas, E. 1896. Neue Selachier-Reste aus dem oberen Lias von Holzmaden in Württemberg. Jahreshefte des Vereins für vaterländische Naturkunde in Württemberg 52: 1-25.

Garman, S. 1913. The Plagiostomia: sharks, skates and rays. Memoirs of the Museum of Comparative Zoology Harvard Collection 36: $1-515$.

Ginter, M., V. Hairapetian, and C. Klug. 2002. Famennian chondrichthyans from the shelves of North Gondwana. Acta Geologica Polonica 52: 169-215.

Glikman, L.S. 1957. [On the relationships between the families Lamnidae and Odontaspidae and on new lamnid genera from the Late Cretaceous]. Trudy Geologicheskogo Muzeja 'A. P. Karpinskogo', Akademia Nauk SSSR 1: 110-117. [in Russian].

Gómez, J.J., A. Goy, and M.L. Canales. 2008. Seawater temperature and carbon isotope variations in belemnites linked to mass extinction during the Toarcian (Early Jurassic) in Central and Northern Spain. Comparison with other European sections. Palaeogeography, Palaeoclimatology, Palaeoecology 258: 28-58. 
Gorjanović-Kramberger, D. 1885. Palaeoichthyolozki prilozi. Rada Jugoslavenske Akademije Znanosti i Umjetnosti 69: 10-65.

Gründel, J. 1999. Gastropoden aus dem höheren Lias von Grimmen, Vorpommern (Deutschland). Archiv für Geschiebekunde 2: 629-672.

Guinot, G., and L. Cavin. 2016. 'Fish' (Actinopterygii and Elasmobranchii) diversification patterns through deep time. Biological Reviews 91: 950-981.

Guinot, G., S. Adnet, and H. Cappetta. 2012. An analytical approach for estimating fossil record and diversification events in sharks, skates and rays. PLoS One 7: e44632. https://doi.org/10.1371/ journal.pone.0044632.

Guinot, G., H. Cappetta, and S. Adnet. 2014. A rare elasmobranch assemblage from the Valanginian (Lower Cretaceous) of southern France. Cretaceous Research 48: 54-84.

Hallam, A. 2001. A review of the broad pattern of Jurassic sea-level changes and their possible causes in the light of current knowledge. Palaeogeography, Palaeoclimatology, Palaeoecology 167: 23-37.

Haq, B.U. 2017. Jurassic sea-level variations: a reappraisal. GSA Today. https://doi.org/10.1130/gsatg359a.1.

Haubold, H. 1990. Ein neuer Dinosaurier (Ornithischia, Thyreophora) aus dem Unteren Jura des nördlichen Mitteleuropa. Revue de Paléobiologie 9: 149-177.

Hay, O.P. 1902. Bibliography and catalogue of the fossil vertebrata of North America. Bulletin of the United States Geological Survey 179: $1-868$.

Herman, J. 1977. Les sélaciens des terrains néocrétacés \& paléocènes de Belgique \& des contrées limitrophes. Eléments d'une biostratigraphie intercontinentale. Mémoires pour servir à l'explication de Cartes Géologiques et Minières de la Belgique. Service Géologique de Belgique 15: 1-401.

Hesselbo, S.P., and H.C. Jenkyns. 1998. British Lower Jurassic sequence stratigraphy. In Mesozoic-Cenozoic Sequence Stratigraphy of European Basins, eds. P.C. de Graciansky, J., Hardenbol, T., Jacquin, M., Farley, and P.R. Vail, P.R., 561-581. (=SEPM Society for Sedimentary Geology, Special Publication $60)$.

Heupel, M.R., and M.B. Bennett. 1998. Observations on the diet and feeding habits of the epaulette shark, Hemiscyllium ocellatum (Bonnaterre), on Heron Island Reef, Great Barrier Reef, Australia. Marine \& Freshwater Research 49: 753-756.

Huxley, T.H. 1880. On the application of the laws of evolution to the arrangement of the Vertebrata, and more particularly of the Mammalia. Proceedings of the Zoological Society of London Meetings of the Zoological Society of London 1880: 649-661.

Ivanov, A. 2005. Early Permian chondrichthyans of the Middle and South Urals. Revista Brasileira de Paleontologia 8: 127-138.

Katzung, G. 2004. Präquartärer Untergrund. In Geologie von Mecklenburg-Vorpommern, ed. G. Katzung, 38-40. Stuttgart: E. Schweizerbart'sche Verlagsbuchhandlung.

Klug, S. 2010. Monophyly, phylogeny and systematic position of the $\uparrow$ Synechodontiformes (Chondrichthyes, Neoselachii). Zoologica Scripta 39: 37-49.

Klug, S., and J. Kriwet. 2006. Anatomy and systematics of the Early Jurassic neoselachian shark Synechodus smithwoodwardi (Fraas, 1896) from southern Germany. Neues Jahrbuch für Geologie und Paläontologie, Monatshefte 2006: 193-211.

Klug, S., and J. Kriwet. 2008. A new basal galeomorph shark (Synechodontiformes, Neoselachii) from the Early Jurassic of Europe. Naturwissenschaften 95: 443-448.

Klug, S., and J. Kriwet. 2013. An offshore fish assemblage (Elasmobranchii, Actinopterygii) from the Late Jurassic of NE Spain. Paläontologische Zeitschrift 87: 235-257.

Klug, S., J. Kriwet, R. Böttcher, G. Schweigert, and G. Dietl. 2009. Skeletal anatomy of the extinct shark Paraorthacodus jurensis
(Chondrichthyes; Palaeospinacidae), with comments on synechodontiform and palaeospinacid monophyly. Zoological Journal of the Linnean Society 157: 107-134.

Konwert, M., and M.K. Hörnig. 2018. Grimmenichthys ansorgei, gen. et sp. nov. (Teleostei, 'Pholidophoriformes'), and other 'pholidophoriform' fishes from the early Toarcian of Grimmen (Mecklenburg-Western Pomerania, Germany). Journal of Vertebrate Paleontology. https://doi.org/10.1080/02724634.2018.1451872.

Konwert, M., and S. Stumpf. 2017. Exceptionally preserved Leptolepidae (Actinopterygii, Teleostei) from the late Early Jurassic Fossil-Lagerstätten of Grimmen and Dobbertin (MecklenburgWestern Pomerania, Germany). Zootaxa 4243: 249-296.

Korte, C., and S.P. Hesselbo. 2011. Shallow marine carbon and oxygen isotope and elemental records indicate icehouse-greenhouse cycles during the Early Jurassic. Paleoceanography 26: PA4219. https://doi.org/10.1029/2011pa002160.

Kriwet, J. 2003. Neoselachian remains (Chondrichthyes, Elasmobranchii) from the Middle Jurassic of SW Germany and NW Poland. Acta Palaeontologica Polonica 48: 583-594.

Kriwet, J. 2004. Late Jurassic selachians (Chondrichthyes: Hybodontiformes, Neoselachii) from Central Portugal. Neues Jahrbuch für Geologie und Paläontologie, Monatshefte 2004: 233-256.

Kriwet, J. 2008. A Late Jurassic carpetshark (Neoselachii, Orectolobiformes) from southern Germany. In Mesozoic Fishes 4-Homology and Phylogeny, eds. G. Arratia, H.-P. Schultze, and M.V.H. Wilson, 443-454. Munich: Verlag Dr. Friedrich Pfeil.

Kriwet, J., and S. Klug. 2004. Late Jurassic selachians (Chondrichthyes, Elasmobranchii) from southern Germany: re-evaluation on taxonomy and diversity. Zitteliana 44: 67-95.

Kriwet, J., and S. Klug. 2008. Diversity and biogeography patterns of Late Jurassic neoselachians (Chondrichthyes: Elasmobranchii). In Fishes and the Break-up of Pangaea, eds. L. Cavin, A. Longbottom, and M. Richter, 55-70. (=Geological Society of London, Special Publication 295).

Kriwet, J., and S. Klug. 2011. A new Jurassic cow shark (Chondrichthyes, Hexanchiformes) with comments on Jurassic hexanchiform systematics. Swiss Journal of Geosciences 104 (Suppl. 1): 107-114.

Kriwet, J., and S. Klug. 2014. Dental patterns of the stem-group hexanchoid shark, Notidanoides muensteri (Elasmobranchii, Hexanchiformes). Journal of Vertebrate Paleontology 34: 1292-1306.

Kriwet, J., and S. Klug. 2015. Knorpelfische (Chondrichthyes). In Solnhofen-Ein Fenster in die Jurazeit 2, eds. G. Arratia, H.-P. Schultze, H. Tischlinger, and G. Viohl, 334-359. Munich: Verlag Dr. Friedrich Pfeil.

Kriwet, J., and S. Klug. 2016. Crassodontidanidae, a replacement name for Crassonotidae Kriwet and Klug, 2011 (Chondrichthyes, Hexanchiformes). Journal of Vertebrate Paleontology 36: e1119698. https://doi.org/10.1080/02724634.2016.1119698.

Kriwet, J., W. Kiessling, and S. Klug. 2009. Diversification trajectories and evolutionary life-history traits in early sharks and batoids. Proceedings of the Royal Society B 276: 945-951.

Kriwet, J., R. Soler-Gijón, and N. López-Martínez. 2007. Neoselachians from the upper Campanian and lower Maastrichtian (Upper Cretaceous) of the southern Pyrenees, northern Spain. Palaeontology 50: 1051-1071.

Kriwet, J., J.M. Lirio, H.J. Nuñez, E. Puceat, and C. Lécuyer. 2006. Late Cretaceous Antarctic fish diversity. In Cretaceous-Tertiary High-Latitude Palaeoenvironments, James Ross Basin, Antarctica, eds. J.E. Francis, D. Pirrie, and J.A. Crame, 83-100. (=Geological Society of London, Special Publications 258).

Kutscher, M. 1988. Zur Invertebratenfauna und Stratigraphie des oberen Pliensbachien von Grimmen (DDR), Echinodermata Freiberger Forschungshefte C 419: 62-70.

Leuzinger, L., G. Cuny, E. Popov, and J.-P. Billon-Bruyat. 2017. A new chondrichthyan fauna from the Late Jurassic of the Swiss 
Jura (Kimmeridgian) dominated by hybodonts, chimaeroids and guitarfishes. Papers in Palaeontology 3: 471-511.

Little, C.T.S., and M.J. Benton. 1995. Early Jurassic mass extinction: a global long-term event. Geology 23: 495-498.

López-Arbarello, A., and E. Sferco. 2018. Neopterygian phylogeny: the merger assay. Royal Society Open Science 5: 172337. https://doi. org/10.1098/rsos.172337.

Maisch, W.M., and J. Ansorge. 2004. The Liassic ichthyosaur Stenopterygius cf. quadriscissus from the lower Toarcian of Dobbertin (northeastern Germany) and some considerations on lower Toarcian marine reptile palaeobiogeography. Paläontologische Zeitschrift 78: 161-171.

Maisch, W.M., and A.T. Matzke. 2016. A new hybodontid shark (Chondrichthyes, Hybodontiformes) from the Lower Jurassic Posidonienschiefer Formation of Dotternhausen, SW Germany. Neues Jahrbuch für Geologie und Paläontologie Abhandlungen 280: 241-257.

Maisey, J.G. 1975. The interrelationships of phalacanthous selachians. Neues Jahrbuch für Geologie und Paläontologie Monatshefte 1975: 563-567.

Maisey, J.G. 1986. The Upper Jurassic hexanchoid elasmobranch Notidanoides n. g. Neues Jahrbuch für Geologie und Paläontologie Abhandlungen 172: 83-106.

Maisey, J.G. 1987. Cranial anatomy of the Lower Jurassic shark Hybodus reticulatus (Chondrichthyes: Elasmobranchii), with comments on hybodontid systematics. American Museum Novitates 2878: 1-39.

Maisey, J.G., G.J.P. Naylor, and D.J. Ward. 2004. Mesozoic elasmobranchs, neoselachian phylogeny and the rise of modern elasmobranch diversity. In Mesozoic Fishes 3-Systematics, Paleoenvironments and Biodiversity, eds. G. Arratia and A. Tintori, 17-56. Munich: Verlag Dr. Friedrich Pfeil.

Maxwell, E.E., and S. Stumpf. 2017. Revision of Saurorhynchus (Actinopterygii: Saurichthyidae) from the Early Jurassic of England and Germany. European Journal of Taxonomy 321: 1-29.

Michelsen, O., L.H. Nielsen, P.N. Johannessen, J. Andsbjerg, and F. Surlyk. 2003. Jurassic lithostratigraphy and stratigraphic development onshore and offshore Denmark. Geological Survey of Denmark and Greenland Bulletin 1: 147-216.

Milner, A.R.C., and J.I. Kirkland. 2006. Preliminary review of the Early Jurassic (Hettangian) freshwater Lake Dixie fish fauna in the Whitmore Point Member, Moenave Formation in southwest Utah. New Mexico Museum of Natural History and Science, Bulletin 37: 510-521.

Müller, J., and F.G.J. Henle. 1837. Ueber die Gattungen der Plagiostomen. Archiv für Naturgeschichte 3: 394-401.

Nordén, K.K., C.J. Duffin, and M.J. Benton. 2015. A marine vertebrate fauna from the Late Triassic of Somerset, and a review of British placodonts. Proceedings of the Geologists' Association 126: 564-581.

Ogg, J.G., G.M. Ogg, and F.M. Gradstein. 2016. A concise geologic time scale: 2016. Amsterdam: Elsevier.

Owen, R. 1846. Lectures on the comparative anatomy and physiology of the vertebrate animals, delivered at the Royal College of Surgeons of England in 1844 and 1846. Part 1. Fishes. London: Longman.

Patterson, C. 1966. British Wealden Sharks. Bulletin of the British Museum (Natural History) 11: 251-350.

Petzka, M., J. Rusbült, and M. Reich. 2004. Jura. In Geologie von Mecklenburg-Vorpommern, ed. G. Katzung, 151-163. Stuttgart: E. Schweizerbart'sche Verlagsbuchhandlung.

Quenstedt, F.A. 1851. Handbuch der Petrefaktenkunde. Tübingen: Laupp.

Quenstedt, F.A. 1858. Der Jura. Tübingen: Laupp.
Rees, J. 1998. Early Jurassic selachians from the Hasle Formation of Bornholm, Denmark. Acta Palaeontologica Polonica 43: 439-452.

Rees, J. 2000. A new Pliensbachian (Early Jurassic) neoselachian shark fauna from southern Sweden. Acta Palaeontologica Polonica 45: 407-424.

Rees, J. 2001. Jurassic and Early Cretaceous selachians-focus on southern Scandinavia. Lund Publications in Geology 153: $1-19$.

Rees, J. 2005. Neoselachian shark and ray teeth from the Valanginian, Lower Cretaceous, of Wąwał, Central Poland. Palaeontology 48: 209-221.

Rees, J. 2008. Interrelationships of Mesozoic hybodont sharks as indicated by dental morphology-preliminary results. Acta Geologica Polonica 58: 217-221.

Rees, J. 2010. Neoselachian sharks from the Callovian-Oxfordian (Jurassic) of Ogrodzieniec near Zawiercie, southern Poland. Palaeontology 53: 887-902.

Rees, J., and G. Cuny. 2007. On the enigmatic neoselachian Agaleus dorsetensis from the European Early Jurassic. GFF 129: 1-6.

Rees, J., and C.J. Underwood. 2002. The status of the shark genus Lissodus, and the position of nominal Lissodus species within the Hybodontoidea. Journal of Vertebrate Paleontology 22: 471-479.

Rees, J., and C.J. Underwood. 2006. Hybodont sharks from the Middle Jurassic of the Inner Hebrides, Scotland. Transactions of the Royal Society of Edinburgh, Earth Sciences 96: 351-363.

Rees, J., and C.J. Underwood. 2008. Hybodont sharks of the English Bathonian and Callovian (Middle Jurassic). Palaeontology 51: 117-147.

Regan, C.T. 1906. A classification of selachian fishes. Proceedings of the Zoological Society of London 1906: 722-758.

Rita, P., M. Reolid, and V. Duarte. 2016. Benthic foraminiferal assemblages record major environmental perturbations during the Late Pliensbachian-Early Toarcian interval in the Peniche GSSP, Portugal. Palaeogeography, Palaeoclimatology, Palaeoecology 454: 267-281.

Röhl, H.J., and A. Schmid-Röhl. 2005. Lower Toarcian (Upper Liassic) black shales of the central European epicontinental Basin: a sequence stratigraphic case study from the SW German Posidonia Shale. In Deposition of Organic-Carbon-Rich Sediments: Models, Mechanisms, and Consequences, ed. N.B. Harris, 165-189. (=SEPM Society for Sedimentary Geology, Special Publication 82).

Romano, M., P. Citton, A. Cipriani, and S. Fabbi. 2018. First report of hybodont shark from the Toarcian Rosso Ammonitico Formation of Umbria-Marche Apennine (Polino area, Terni, Central Italy). Italian Journal of Geosciences 137: 151-159.

Rosales, I., S. Quesada, and S. Robles. 2004. Paleotemperature variations of Early Jurassic seawater recorded in geochemical trends of belemnites from the Basque-Cantabrian basin, northern Spain. Palaeogeography, Palaeoclimatology, Palaeoecology 203: 253-275.

Roux, W. 1887. Über eine im Knochen lebende Gruppe von Fadenpilzen (Mycelites ossifragus). Zeitschrift für wissenschaftliche Zoologie 45: 227-254.

Schmidt, M. 1921. Hybodus hauffianus und die Belemnitenschlachtfelder. Jahreshefte des Vereins für vaterländische Naturkunde in Württemberg 77: 103-107.

Schweizer, A. 1964. Elasmobranchier und Holocephalen aus den Nusplinger Plattenkalken. Palaeontographica, Abteilung A 123: 58-110.

Simonsen, S. 2012. Weitere Buttenheimer Fauna und Flora. Der Steinkern 2: 48-57. 
Smith, A. 1837. On the necessity for a revision of the groups included in the Linnean genus Squalus. Proceedings of the Zoological Society of London 5: 85-86.

Srdic, A., C.J. Duffin, and D.M. Martill. 2016. First occurrence of the orectolobiform shark Akaimia in the Oxford Clay Formation (Jurassic, Callovian) of England. Proceedings of the Geologists' Association 127: 506-513.

Stumpf, S. 2016. New information on the marine reptile fauna from the lower Toarcian (Early Jurassic) "Green Series" of North-Eastern Germany. Neues Jahrbuch für Geologie und Paläontologie, Abhandlungen 280: 87-105.

Stumpf, S., J. Ansorge, and W. Krempien. 2015. Gravisaurian sauropod remains from the late Early Jurassic (Lower Toarcian) of NorthEastern Germany. Geobios 48: 271-279.

Stumpf, S., J. Ansorge, C. Pfaff, and J. Kriwet. 2017. Early Jurassic diversification of pycnodontiform fishes (Actinopterygii, Neopterygii) after the end-Triassic extinction event: evidence from a new genus and species, Grimmenodon aureum. Journal of Vertebrate Paleontology 37: e1344679. https://doi.org/10.1080/02724 634.2017.1344679.

Suan, G., E. Mattioli, B. Pittet, C. Lécuyer, B. Suchéras-Marx, L.V. Duarte, M. Philippe, L. Reggiani, and F. Martineau. 2010. Secular environmental precursors to Early Toarcian (Jurassic) extreme climate changes. Earth and Planetary Science Letters 290: 448-458.

Thies, D. 1983. Jurazeitliche Neoselachier aus Deutschland und S-England. Courier Forschungsinstitut Senckenberg 58: 1-116.

Thies, D. 1989. Sinneslinien bei dem Knochenfisch Lepidotes elvensis (Blainville 1818) (Actinopterygii, Semionotiformes) aus dem Oberlias (Unter-Toarcium) von Grimmen in der DDR. Neues Jahrbuch für Geologie und Paläontologie, Monatshefte 1989: 692-704.

Thies, D. 1992. A new species of Palaeospinax (Chondrichthyes, Neoselachii) from the Lower Jurassic Posidonia Shale of southern Germany. Paläontologische Zeitschrift 66: 137-146.

Thies, D. 1993. Palaeospinax, Synechodus and/or Paraorthacodus. Is the problem of palaeospinacid genera (Pisces, Neoselachii) solved? Neues Jahrbuch für Geologie und Paläontologie, Monatshefte 1993(12): 724-732.

Thies, D., and A. Leidner. 2011. Sharks and guitarfishes (Elasmobranchii) from the Late Jurassic of Europe. Palaeodiversity 4: 63-184.

Thies, D., and W.-E. Reif. 1985. Phylogeny and evolutionary ecology of Mesozoic Neoselachii. Neues Jahrbuch für Geologie und Paläontologie, Abhandlungen 169: 333-361.

Thiollière, V. 1852. Troisième notice sur les gisements a poissons fossiles situés dans le Jura du département de l'Ain. Annales des Sciences Physiques et Naturelles,' Agriculture et d'Industrie 2: 353-446.

Tittensor, D.P., C. Mora, W. Jetz, H.K. Lotze, D. Ricard, E. Vanden Berghe, and B. Worm. 2010. Global patterns and predictors of marine biodiversity across taxa. Nature 466: 1098-1101.

Trautschold, H. 1877. Über Kreidefossilien Russlands. Bulletin de la Société des Naturalistes de Moscou 11: 332-349.

Underwood, C.J. 2004. Environmental controls on the distribution of neoselachian sharks and rays within the British Bathonian (Middle Jurassic). Palaeogeography, Palaeoclimatology, Palaeoecology 203: 107-126.

Underwood, C.J. 2006. Diversification of the Neoselachii (Chondrichthyes) during the Jurassic and Cretaceous. Paleobiology 32: 215-235.

Underwood, C.J., and K.M. Claeson. 2017. The Late Jurassic ray Kimmerobatis etchesi gen. et. sp. nov. and the Jurassic radiation of Batoidea. Proceedings of the Geologist's Association. https://doi. org/10.1016/j.pgeola.2017.06.009.
Underwood, C.J., and S.F. Mitchell. 1999. Albian and Cenomanian selachian assemblages from North-East England. Special Papers in Palaeontology 60: 9-56.

Underwood, C.J., and J. Rees. 2002. Selachian faunas from the earliest Cretaceous Purbeck Group of Dorset, southern England. Special Papers in Palaeontology 68: 83-101.

Underwood, C.J., and D.J. Ward. 2004. Neoselachian sharks and rays from the British Bathonian (Middle Jurassic). Palaeontology 47: 447-501.

Underwood, C.J., S.F. Mitchell, and K.J. Veltkamp. 1999. Microborings in mid-Cretaceous fish teeth. Proceedings of the Yorkshire Geological Society 52: 269-274.

Vajda, V., and J. Wigforss-Lange. 2009. Onshore Jurassic of Scandinavia and related areas. GGF 131: 5-23.

Vincent, P., J.E. Martin, V. Fischer, G. Suan, B. Khalloufi, B. SuchérasMarx, A. Lena, K. Janneau, B. Rousselle, and L. Rulleau. 2013. Marine vertebrate remains from the Toarcian-Aalenian succession of southern Beaujolais, Rhône, France. Geological Magazine 150: 822-834.

Vullo, R., H. Cappetta, and D. Néraudeau. 2007. New sharks and rays from the Cenomanian and Turonian of Charentes, France. Acta Palaeontologica Polonica 52: 99-116.

Wagner, A. 1862. Monographie der fossilen Fische aus den lithographischen Schiefern Bayerns. Abhandlungen der mathematischphysikalischen Classe der königlich bayerischen Akademie der Wissenschaften 9: 277-352.

Ward, D.J., and D. Thies. 1987. Hexanchid shark teeth (Neoselachii, Vertebrata) from the Lower Cretaceous of Germany and England. Mesozoic Research 1: 89-106.

Weigmann, S. 2016. Annotated checklist of the living sharks, batoids and chimaeras (Chondrichthyes) of the world, with a focus on biogeographical diversity. Journal of Fish Biology 88: 837-1037.

Whitenack, L.B., and P.J. Motta. 2010. Performance of shark teeth during puncture and draw: implications for the mechanics of cutting. Biological Journal of the Linnean Society 100: 271-286.

Wignall, P.B., R.J. Newton, and C.T.S. Little. 2005. The timing of paleoenvironmental change and cause-and-effect relationships during the Early Jurassic mass extinciton in Europe. American Journal of Science 305: 1014-1032.

Woodward, A.S. 1887. Notes on some post-Liassic species of Acrodus. Geological Magazine 4: 101-105.

Woodward, A.S. 1888. On the Cretaceous selachian genus Synechodus. Geological Magazine 3: 496-499.

Woodward, A.S. 1889. Catalogue of the fossil fishes in the British Museum (Natural History). Part I. Elasmobranchii. London: Taylor and Francis.

Woodward, A.S. 1919. On two new elasmobranch fishes (Crossorhinus jurassicus, sp. nov. and Protospinax annectans, gen. et sp. nov.) from the Upper Jurassic lithographic stone of Bavaria. Proceedings of the Zoological Society of London 13: 231-235.

Wright, S., J. Keeling, and L. Gillman. 2006. The road from Santa Rosalia: a faster tempo evolution in tropical climates. Proceedings of the National Academy of Sciences USA 103: 7718-7722.

Wright, S.D., H.A. Ross, D.J. Keeling, P. McBride, and L.N. Gillman. 2011. Thermal energy and the rate of genetic evolution in marine fishes. Evolutionary Ecology 25: 525-530.

Zittel, K.A. von. 1911. Grundzüge der Paläontologie (Paläozoologie). II. Abteilung: Vertebrata, 2nd ed. Berlin, Munich: R. Oldenbourg. 